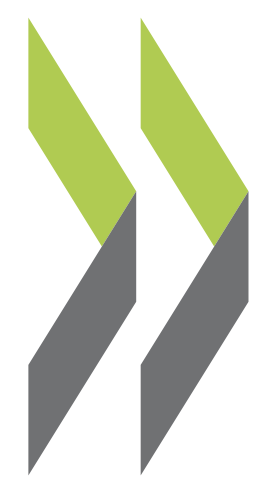

OECD Economics Department Working Papers No. 1580

Tax and benefit reforms to support employment and inclusiveness and address poverty in Italy

\section{Tim Bulman,}

Daniele Pacifico,

Mauro Pisu,

Olga Rastrigina 


\section{ECONOMICS DEPARTMENT}

\section{TAX AND BENEFIT REFORMS TO SUPPORT EMPLOYMENT AND INCLUSIVENESS AND ADDRESS POVERTY IN ITALY}

\section{ECONOMICS DEPARTMENT WORKING PAPERS No. 1580}

By Tim Bulman, Daniele Pacifico, Mauro Pisu and Olga Rastrigina

OECD Working Papers should not be reported as representing the official views of the OECD or of its member countries. The opinions expressed and arguments employed are those of the author(s).

Authorised for publication by Isabell Koske, Deputy Director, Country Studies Branch, Economics Department.

All Economics Department Working Papers are available at www.oecd.org/eco/workingpapers.

JT03455450 
OECD Working Papers should not be reported as representing the official views of the OECD or of its member countries. The opinions expressed and arguments employed are those of the author(s).

Working Papers describe preliminary results or research in progress by the author(s) and are published to stimulate discussion on a broad range of issues on which the OECD works.

Comments on Working Papers are welcomed, and may be sent to OECD Economics Department, 2 rue André Pascal, 75775 Paris Cedex 16, France, or by e-mail to eco.contact@oecd.org.

All Economics Department Working Papers are available at www.oecd.org/eco/workingpapers.

On 25 May 2018, the OECD Council invited Colombia to become a Member. At the time of preparation, the deposit of Colombia's instrument of accession to the OECD Convention was pending and therefore Colombia does not appear in the list of OECD Members and is not included in the OECD zone aggregates.

This document and any map included herein are without prejudice to the status of or sovereignty over any territory, to the delimitation of international frontiers and boundaries and to the name of any territory, city or area.

The statistical data for Israel are supplied by and under the responsibility of the relevant Israeli authorities. The use of such data by the OECD is without prejudice to the status of the Golan Heights, East Jerusalem and Israeli settlements in the West Bank under the terms of international law.

\section{(C) OECD (2019)}

You can copy, download or print OECD content for your own use, and you can include excerpts from OECD publications, databases and multimedia products in your own documents, presentations, blogs, websites and teaching materials, provided that suitable acknowledgment of OECD as source and copyright owner is given. All requests for commercial use and translation rights should be submitted to rights@oecd.org 


\section{ABSTRACT/RESUMÉ}

\section{Tax and benefit reforms to support employment and inclusiveness and address poverty in Italy}

This paper assesses Italy's 2019 tax and benefit reforms, analyses hypothetical reforms and proposes a reform package that balances goals of reducing poverty, encouraging employment and fiscal sustainability. Using the OECD's Tax-Benefit and the EUROMOD microsimulation models, it shows that the new guaranteed minimum income scheme introduced in 2019 significantly strengthens Italy's low income protection system but can also financially discourage recipients from working. The debated flattening of personal income tax rates would do little to improve work incentives, but would drastically cut tax revenues and increase inequality, by reducing the progressivity of the personal tax system. A proposed reform package that maintains progressive personal income tax rates, gradually withdraws low-income support and provides additional benefits for low-wage earners would make inroads into poverty and inequality while encouraging formal work. This paper accompanies and extends the results of the in-depth chapter of the OECD 2019 Economic Survey of Italy $\left(2019_{[1]}\right)$ on social and regional disparities.

This Working Paper relates to the 2019 OECD Economic Survey of Italy (http://www.oecd.org/economy/italy-economic-snapshot/).

JEL codes: H22; H310; H53; H55; J32; I38; J38; D3.

Keywords: tax-benefit policies, labour supply, tax wedge, in-work benefits, guaranteed minimum income, active labour market policies, inequality, poverty, labour force participation, work incentives

\section{Réformer les prélèvements et prestations pour soutenir l'emploi et l'inclusivité et combattre la pauvreté en Italie}

Ce document évalue les réformes des prélèvements et prestations menées en Italie en 2019, analyse les projets de réforme actuellement débattus et propose un programme alternatif qui concilie les objectifs de réduire la pauvreté, d'encourager l'emploi et de favoriser la viabilité budgétaire. Utilisant les modèles de microsimulation - OECD Tax-Benefit and the EUROMOD - l'étude montre que le nouveau système de revenu minimum garanti mis en place en 2019 renforce considérablement le système de protection des bas revenus en Italie, mais peut aussi diminuer les incitations au travail de ses bénéficiaires. Le nivellement envisagé du barème de l'impôt sur le revenu des personnes physiques ne contribuerait guère à améliorer les incitations au travail, mais entraînerait une baisse drastique des recettes fiscales et accroîtrait les inégalités, en réduisant la progressivité de cet impôt. Un programme de réformes alternatif qui maintient la progressivité du barème de l'impôt sur le revenu des personnes physiques, et qui supprime progressivement le soutien aux bas revenus et alloue des prestations supplémentaires aux titulaires de bas salaires contribuerait à résorber la pauvreté et les inégalités tout en encourageant l'activité formelle. Ce document complète et approfondit les résultats du chapitre détaillé de l'Étude économique OCDE 2019 de l'Italie $\left(2019_{[1]}\right)$ consacré aux disparités sociales et régionales.

Ce document de travail se rapporte à l'Etude Economique d'Italie 2019

(http://www.oecd.org/fr/economie/italie-en-un-coup-d-oeil/).

JEL classification : H22; H310; H53; H55; J32; I38; J38; D3.

Mots de Clés: Politiques fiscales et sociales, coin socio-fiscal, prestations liées à l'emploi, revenu minimum, politiques actives du marché du travail, inégalités, pauvreté, participation au marché du travail, incitations au travail. 


\section{Table of contents}

\section{Tax and benefit reforms to support employment and inclusiveness and} address poverty in Italy

1. Introduction 6

1.1. Italy's large tax and benefit system falls short of redressing poverty and supporting inclusion $\quad 6$

1.2. The tax and benefit system imposes high effective tax rates when entering employment $\quad 10$

$\begin{array}{lr}\text { 1.3. Work incentives are weaker in lagging regions } & 10\end{array}$

2. Developing a minimum income scheme in Italy 12

2.1. Italy has progressively introduced a guaranteed minimum income targeting poor households $\quad 12$

3. Assessing the Citizen's Income and two hypothetical tax and benefit policy reforms 14

3.1. The Citizen's Income raises support for low-income families but weakens work incentives $\quad 16$

3.2. Flattening personal tax rates would sharply cut revenues and benefit high income households $\quad 30$

3.3. Reforming the guaranteed minimum income and introducing in-work benefits would raise poor

households' incomes $\quad 32$

4. Summary and conclusion $\quad 36$

Annex. Proposed reform package of guaranteed minimum income, in-work benefits and family allowances 37

$\begin{array}{ll}\text { Proposed guaranteed minimum income } & 37\end{array}$

$\begin{array}{ll}\text { Proposed in-work benefit } & 38\end{array}$

$\begin{array}{ll}\text { Proposed family allowance } & 39\end{array}$

$\begin{array}{ll}\text { References } & 40\end{array}$

\section{Tables}

Table 1. Main tax credits and allowances in Italy, $2018 \quad 9$

$\begin{array}{lr}\text { Table 2. Tax-benefit policies discussed in this paper } & 10\end{array}$

Table 3. Italy's expanding guaranteed minimum income programmes 14

Table 4 . The rent and mortgage allowances raise the Citizen's Income for single person households above some poverty 22
lines

Table 5. The Citizen's Income equivalence scales penalise large households 23

Table 6. Effects of tax and benefit policy reforms on poverty, inequality and public expenditure 24

Table 7. Guaranteed minimum income programme costs are limited compared with the large revenue loss from a

flattened personal income tax rate schedule $\quad 28$

Table 8. Tax and benefit reforms need to support both employment and productivity to lift GDP growth in the long-term 29

Table 9. Hypothetical flatter personal income tax scenario 31

Table 10. A proposed tax and benefit reform package introducing low-wage in-work benefits, a refined guaranteed

minimum income scheme and simpler personal income tax system 


\section{Figures}

Figure 1. A small share of transfers benefits Italy's poorest households

Figure 2. Activity rates vary between regions among women more than among men

Figure 3. Italy's former guaranteed minimum income provided limited transfers, while the new Citizen's Income is relatively generous for single-person households

Figure 4. Italy's effective tax rates on entering employment are high for second earners

Figure 5. The Citizen's Income raises the effective tax rates on entering employment at low wages, weakening incentives to enter formal employment

Figure 6. The Citizen's Income introduces a floor for households' incomes

Figure 7. Effective tax rates on increasing working hours are high in Italy

Figure 8 . Households headed by the unemployed, sick or disabled and students particularly benefit from guaranteed minimum income policies

Figure 9. Living costs are lower for low-income households in southern and rural areas

Figure 10. Targeted income support is likely to particularly benefit residents of southern regions

Figure 11. Guaranteed minimum incomes boost very low income households while flattened personal income tax rates would largely benefit higher income households

\section{Boxes}

Box 1. A short overview of the evolution of minimum income schemes in Italy

Box 2. Tax and benefit policy outcomes and indicators 


\title{
Tax and benefit reforms to support employment and inclusiveness and address poverty in Italy
}

\author{
By Tim BULMAN, Daniele PACIFICO, Mauro PISU and Olga RASTRIGINA ${ }^{1}$
}

\section{Introduction}

\subsection{Italy's large tax and benefit system falls short of redressing poverty and supporting inclusion}

1. Italy's tax and benefit system mobilises and transfers a larger share of GDP than most other OECD countries' systems (OECD, 2019 $\left.{ }_{[1]}\right)$. Italy has made important reforms over recent years to strengthen the support for the poorest households, notably by expanding guaranteed minimum income schemes. The system makes inroads into inequality and poverty, yet after taxes and transfers, both poverty and inequality rates remain in the upper half of OECD countries, partly due to the poor targeting of benefits to Italy's poorest households (Figure 1). Moreover, the labour income tax wedge, i.e. the difference between the cost of employing a worker and that worker's disposable income, is among the largest of any OECD country. The high taxation of labour reduces labour demand and discourages employment in the formal sector (OECD, 2019 $9_{[2]}$ ). The structure of tax rates, tax credits and benefits further lowers work incentives, especially at lower wage rates and for second earners, who are largely women. This contributes to the large regional variation in employment rates, which is especially pronounced among women at low wage rates (Figure 2).

2. Italy has implemented important reforms over recent years to strengthen the support for the poorest households. In April 2019 the government replaced the guaranteed minimum income programme introduced in 2018, "Reddito di Inclusione" (REI), with a new Citizen's Income scheme, "Reddito di Cittadinanza" (CI), characterized by a higher level of coverage and benefit amounts (Figure 3).

\footnotetext{
${ }^{1}$ An earlier version of this paper benefited from the comments of Sebastian BARNES, Bert BRYS and Paula GARDA. Federico GIOVANNELLI provided statistical research assistance and Heloise WICKRAMANAYAKE provided editorial support. The corresponding author is Tim BULMAN, email: tim.bulman@,oecd.org.
} 
Figure 1. A small share of transfers benefits Italy's poorest households

Share of total transfers received by the poorest $20 \%$ of working age population, 2016 or latest available year

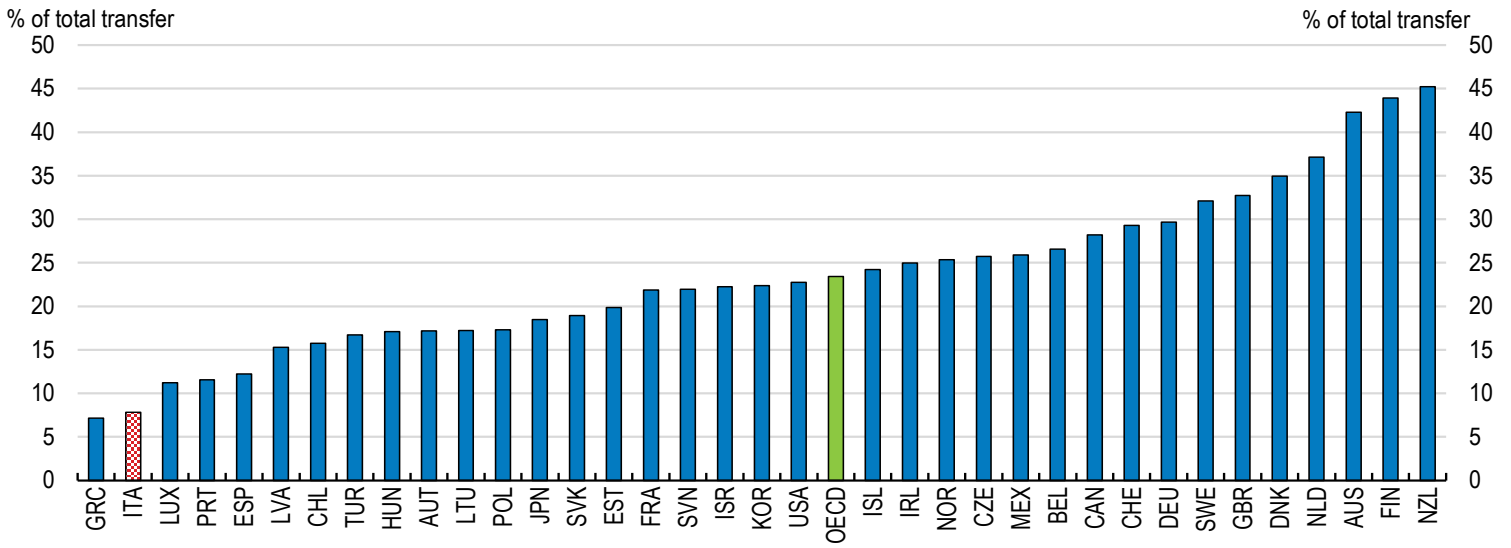

Note: Public social transfers received (from public social security) by working-age individuals in low-income groups (equivalised disposable income). Age group 18-65, 18-62 in France.

Source: OECD calculations based on the OECD Income Distribution database.

Figure 2. Activity rates vary between regions among women more than among men

Labour force participation rate of working-age population (20-64 year olds) by region and education level (2017) in percent, and average wages per hour (2015) Euros
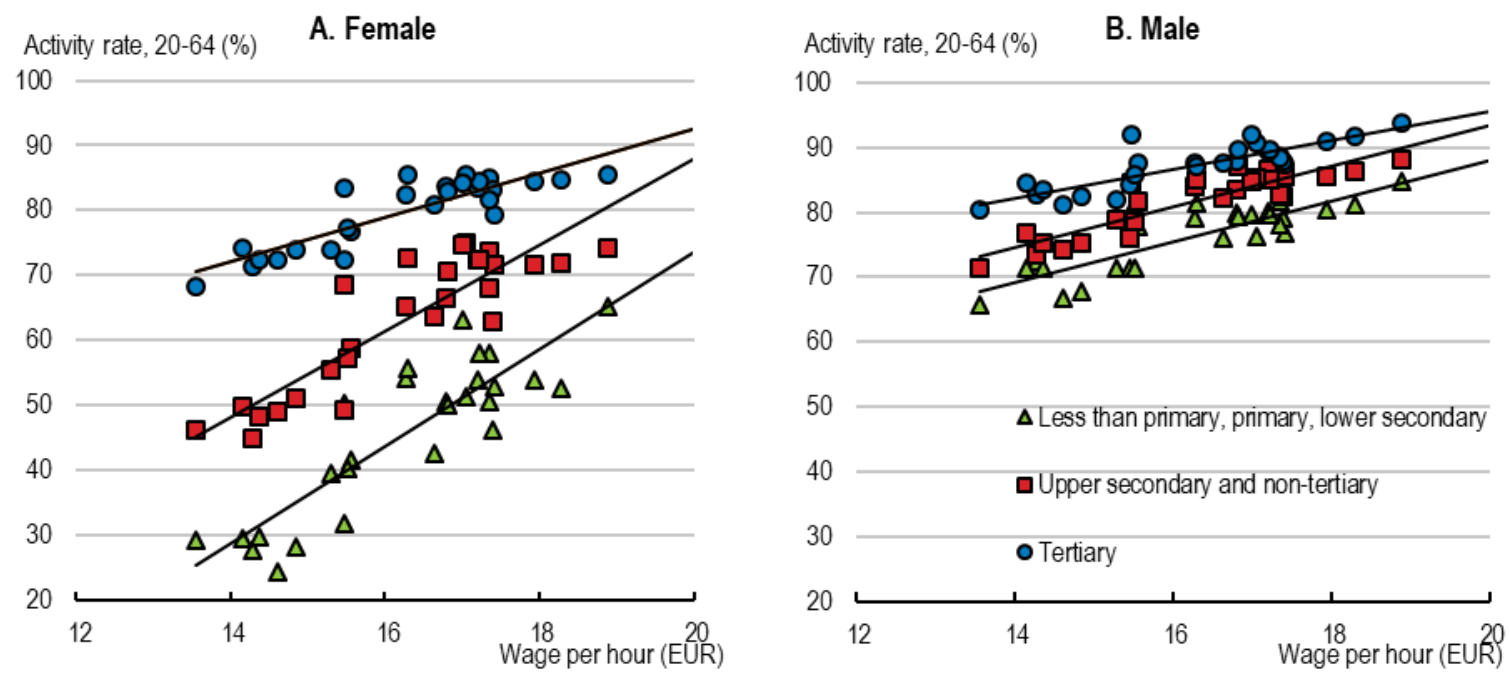

Note: Wage data are only region and gender specific, and cover workers aged 15 and older.

Source: ISTAT and Eurostat

3. Despite these reforms, Italy's existing tax and benefit system remains poorly targeted, discourages second earners from working, and is fragmented across different programmes. Table 1 summarises the main allowances and tax credits. Workers in couples receive a tax credit for a dependent spouse, which pushes up their tax burden once the spouse enters employment. Eligibility for the main family allowance ("Assegni al Nucleo Familiare") requires at least $70 \%$ of household income to come from employment, so jobless households as well as those in non-standard employment are not covered by this measure. Working families receive additional support for their 
children through a system of family tax credits, which are non-refundable and provide little support to low earners. A prototype in-work benefit, a "fiscal bonus" of EUR 80 per month, reduces net taxes faced by employees earning up to $80 \%$ of the national average wage. Those earning less than $30 \%$ of the national average wage are ineligible for the bonus. For those with earnings close to $80 \%$ of the average wage, the bonus withdrawal is steep, producing high marginal effective tax rates that discourage raising earnings, for example by working longer hours.

Figure 3. Italy's former guaranteed minimum income provided limited transfers, while the new Citizen's Income is relatively generous for single-person households

Net household income of jobless households receiving guaranteed minimum income, as a \% of median disposable income in the population, 2018 policies

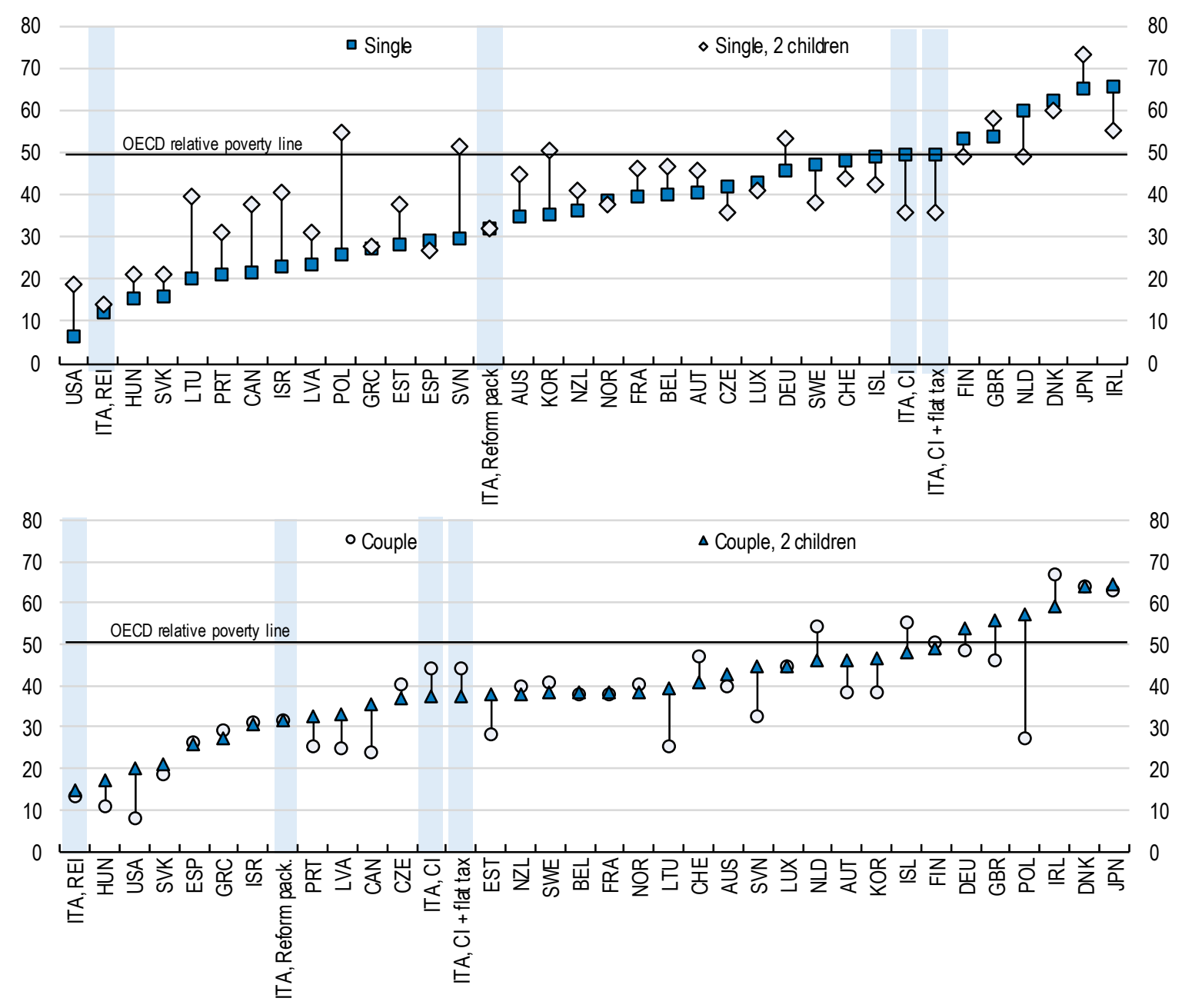

Note: "ITA, REI" shows the policy rules relating to the 2018 "Reddito di inclusion", the guaranteed minimum income implemented in 2018; "ITA, CI" reflects the Citizen's Income policy rules prescribed by the decree of January 2019; and "ITA, Reform pack." reflects the policy rules relating to the hypothetical guaranteed minimum income in the proposed policy package presented in Table 10 .

Source: Calculations based on the OECD Tax-benefit model.

4. This paper analyses recently introduced tax and benefit reforms and other reforms that are currently under discussion. It then proposes a broader reform package to 
strengthen the progressivity of the income tax schedule and increase support for lowincome families with children. Table 2 summarises the alternative policies discussed in this paper. The paper first discusses the current tax credit and allowance system's poor targeting and financial disincentives for second earners to work at low wages, and the relationship this has with the low employment rates in Italy's lagging regions. It then assesses recently introduced tax and benefit reforms and analyses reforms that are currently under discussion, focusing on their effects on public finances, financial work incentives, income distribution, poverty and inequality. Finally, the paper proposes a broader reform package to strengthen the progressivity of the income tax schedule, increase support for low-income families with children and provide in-work benefits for low-wage earners. This paper complements and deepens the discussion in the 2019 OECD Economic Survey of Italy (OECD, 2019 $\left.{ }_{[1]}\right)$.

Table 1. Main tax credits and allowances in Italy, 2018

\begin{tabular}{|c|c|}
\hline $\begin{array}{l}\text { 1. Low income tax } \\
\text { credit }\end{array}$ & $\begin{array}{l}\text { Non-refundable tax credit of EUR } 1880 \text { for dependent employment incomes below EUR } 8000 \text { per year. } \\
\text { Credit declines as income rises up to EUR } 55000 \text {. Other income sources, such as self-employment and } \\
\text { old age pension receive specific tax credits. The credit declines in proportion to the number of days } \\
\text { worked per fiscal year. The tax credit cannot be lower than EUR } 690 \text { (EUR } 1380 \text { for temporary } \\
\text { contracts). }\end{array}$ \\
\hline 2. Family tax credits & $\begin{array}{l}\text { Applies for the taxpayer's dependents provided their income is below EUR } 2841 \text { per year. } \\
\text { 1) For dependent children: for children under three years of age the tax credit is computed as } \\
\text { EUR } 1220^{*}(95000 \text {-taxable income }) / 95000 \text {; for children over three years of age it is computed as: } \\
\text { EUR } 950^{*}\left(95000 \text {-taxable income } / 95000 \text {. Amounts are increased by EUR } 15000 \text { for the additional } 2^{\text {nd }}\right. \\
\text { and } 3 \text { rd children and by more for additional children. For two-earner couples, the tax credits are equally } \\
\text { shared between the parents. However, if the second earner's tax liability after the income-related tax } \\
\text { credit is less than their half of the child tax credit, the entire child tax credit is allocated to the other } \\
\text { partner. } \\
\text { 2) For a dependent spouse: For main earner with income up to EUR } 15000 \text {, the main earner gains a } \\
\text { credit of EUR } 800-110^{*} \text { taxable income } / 15000 \text {. The credit declines to } 0 \text { at income of EUR } 80000 \text {. } \\
\text { 3) For other dependent relatives the tax credit is computed as } 750^{*}(80000 \text {-taxable income }) / 80000 \text {. }\end{array}$ \\
\hline 3. Fiscal bonus & $\begin{array}{l}\text { Income up to EUR } 8 \text { 145: bonus of EUR 0. Income EUR } 8146-24600 \text {, credit of EUR } 960 \\
\text { (EUR } 80 \text { per month). Credit declines to } 0 \text { between incomes of EUR } 24600 \text { and EUR } 26600 \text {. The bonus } \\
\text { is scaled by the number of days worked per fiscal year. Only applies when there is a tax liability after } \\
\text { low income tax credit. }\end{array}$ \\
\hline $\begin{array}{l}\text { 4. Housing rental tax } \\
\text { credit }\end{array}$ & Income below EUR 15 493.71, credit of EUR 300. If income below EUR 30 987.41, credit of EUR 150. \\
\hline 5. Childcare tax credit & Tax rebate of $19 \%$ of childcare expenses, up \\
\hline 6. Family allowance & $\begin{array}{l}\text { Non-taxable cash transfers to employees, unemployment benefit recipients and former-employee } \\
\text { pensioners; it does not cover the self-employed. At least } 70 \% \text { of income must come from employment } \\
\text { (including unemployment benefits). }\end{array}$ \\
\hline $\begin{array}{l}\text { 7. Large family } \\
\text { allowance }\end{array}$ & $\begin{array}{l}\text { Non-taxable cash transfer. At least } 3 \text { children. EUR } 141.30 \text { per month, and EUR } 500 \text { additional } \\
\text { allowance if more than } 4 \text { children. ISEE } 1 \text { value below EUR } 8555 \text {. }\end{array}$ \\
\hline 8. Baby bonus & $\begin{array}{l}\text { Non-taxable transfer, EUR } 160 \text { per month if ISEE below EUR } 7000 \text { or EUR } 80 \text { per month if ISEE below } \\
\text { EUR } 25000 \text {, per child for } 12 \text { months }\end{array}$ \\
\hline
\end{tabular}

Note: 1. The ISEE ('equivalent economic situation indicator') is a summary indicator of a household's income and assets, adjusted for the number and characteristics of household members. The ISEE is used to assess households' eligibility for means-tested benefits. For more details, see Box 1.4 in (OECD, 2019[1]).

Source: $\underline{\text { OECD Tax and Benefit policy database. }}$ 
Table 2. Tax-benefit policies discussed in this paper

\begin{tabular}{|c|c|c|c|}
\hline $\begin{array}{l}\text { Tax-benefit } \\
\text { policy }\end{array}$ & $\begin{array}{c}\text { Abbreviated } \\
\text { label }\end{array}$ & Status of policy & Comments \\
\hline $\begin{array}{l}2018 \text { policies } \\
\text { (the baseline) }\end{array}$ & REI & $\begin{array}{l}\text { Operated nationally July } \\
2018 \text { to April } 2019\end{array}$ & $\begin{array}{l}\text { The tax-benefit policies in place at the end of } 2018 \text { including the REI guaranteed } \\
\text { minimum income policy rolled out in July } 2018 \text {, are the baseline for comparisons } \\
\text { in this paper. }\end{array}$ \\
\hline Citizen's Income & $\mathrm{Cl}$ & $\begin{array}{l}\text { Replaced REI in April } \\
2019\end{array}$ & $\begin{array}{l}\text { The "Citizen's Income" was introduced in April } 2019 \text { and replaced the REI. The } \\
\text { Cl's transfers and eligibility thresholds are more generous than those of the REI. } \\
\text { Overall, the } \mathrm{Cl} \text { could lower poverty rates and the poverty gap substantially. } \\
\text { Beneficiaries will only retain a small share of any gains in employment income, } \\
\text { and only for the length of their ongoing } \mathrm{Cl} \text { 'pact'. This, interacting with other } \\
\text { aspects of the tax and benefit system, risks discouraging recipients from } \\
\text { obtaining full-time employment in the formal sector. Job search and other } \\
\text { obligations of Cl beneficiaries are intended to offset these disincentives but need } \\
\text { improved administrative capacity. }\end{array}$ \\
\hline $\begin{array}{l}\text { Flattening the } \\
\text { personal } \\
\text { income tax rate } \\
\text { schedule }\end{array}$ & $\begin{array}{l}\mathrm{Cl}+\text { flattened } \\
\text { tax }\end{array}$ & $\begin{array}{l}\text { Proposals to flatten } \\
\text { personal income tax } \\
\text { rates schedule have } \\
\text { been discussed for some } \\
\text { time in Italy }\end{array}$ & $\begin{array}{l}\text { Flatter personal income tax rate schedules with fewer steps have been } \\
\text { discussed for some time. The effects of flatter income tax rate schedule in } \\
\text { conjunction with the Citizen's Income warrant assessing, as these measures are } \\
\text { likely to be highly costly. Without changes in deductions and allowances to } \\
\text { maintain the progressivity of personal income tax, flatter income tax schedules } \\
\text { will largely benefit high income households, without improving work incentives } \\
\text { for low-income households. }\end{array}$ \\
\hline $\begin{array}{l}\text { Proposed tax } \\
\text { and benefit } \\
\text { reform package }\end{array}$ & $\begin{array}{l}\text { Reform } \\
\text { package }\end{array}$ & $\begin{array}{l}\text { Tax and benefit reform } \\
\text { package proposed in the } \\
2019 \text { OECD Economic } \\
\text { Survey of Italy (OECD, } \\
\left.2019_{[1]}\right)\end{array}$ & $\begin{array}{l}\text { This would consist of a refined guaranteed minimum income, together with in- } \\
\text { work benefits for low-wage earners, and a simpler system of personal income } \\
\text { tax and family benefits. This structure may better protect households from } \\
\text { poverty and encourage formal sector employment, especially among second } \\
\text { earners, at a moderate net cost for public finances. This policy mix draws on } \\
\text { many countries' experiences in addressing the same objectives. }\end{array}$ \\
\hline
\end{tabular}

\subsection{The tax and benefit system imposes high effective tax rates when entering employment}

5. In Italy, taxes paid and benefits received depend on household composition (Table 1). This involves trade-offs between equity and efficiency. In general, the more dependent an individual's effective tax liability is on other household members' incomes, the greater the disincentive for the second earners to seek employment. This can create divergences in tax treatment between otherwise similar households, with the divergences generally larger at lower incomes.

6. The Citizen's Income has rightly increased the resources allocated to anti-poverty programmes and, if well implemented (as discussed below), can contribute to reducing poverty. However, as shown in Figure 4, the current tax and benefit rules generate high effective tax rates for second earners when entering work at moderate wage rates. This will further discourage the unemployed and people outside the labour force from finding formal-sector jobs.

\subsection{Work incentives are weaker in lagging regions}

7. Labour market conditions in lagging regions amplify the tax and benefit system's work disincentives, contributing to markedly lower employment rates especially among women (Figure 2). The average wage in southern regions is $14 \%$ below the national average, which corresponds to between the $30^{\text {th }}$ and $40^{\text {th }}$ percentiles of the national full-time wage distribution, while wages in most northern regions are between the $60^{\text {th }}$ and $80^{\text {th }}$ percentiles. Informal work is more common in lagging regions, giving workers and firms in these regions more opportunities to work and produce without paying taxes and social security contributions. 
Figure 4. Italy's effective tax rates on entering employment are high for second earners Effective tax rate on entering employment, \%
$\%$
A. Two-earner couple*

60 One partner earns $50 \%$ of average wage, the 2 nd starts working at $50 \%$ of the average wage

One partner earns the average wage, the 2nd starts working at $50 \%$ of the average wage

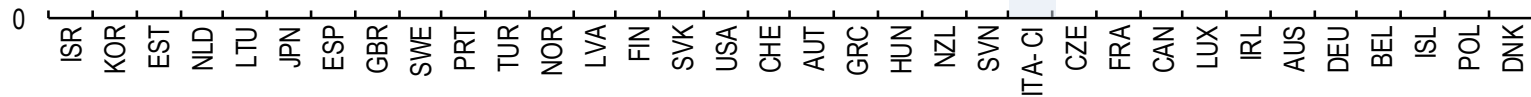
B. One-earner couple

100 Couple, 1 partner starts working at $65 \%$ of the average wage
Couple, 2 children, 1 partner starts working at $65 \%$ of the average wage

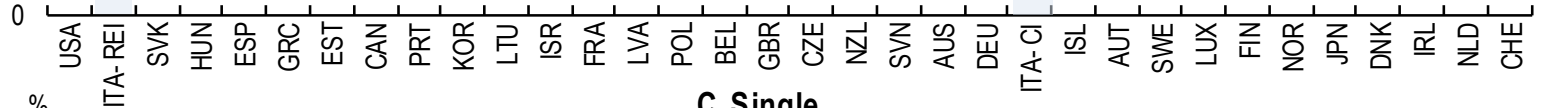
$100 \%$ Single, starts working at $65 \%$ of the average wage

॰ Single, 2 children, starts working at $65 \%$ of the average wage

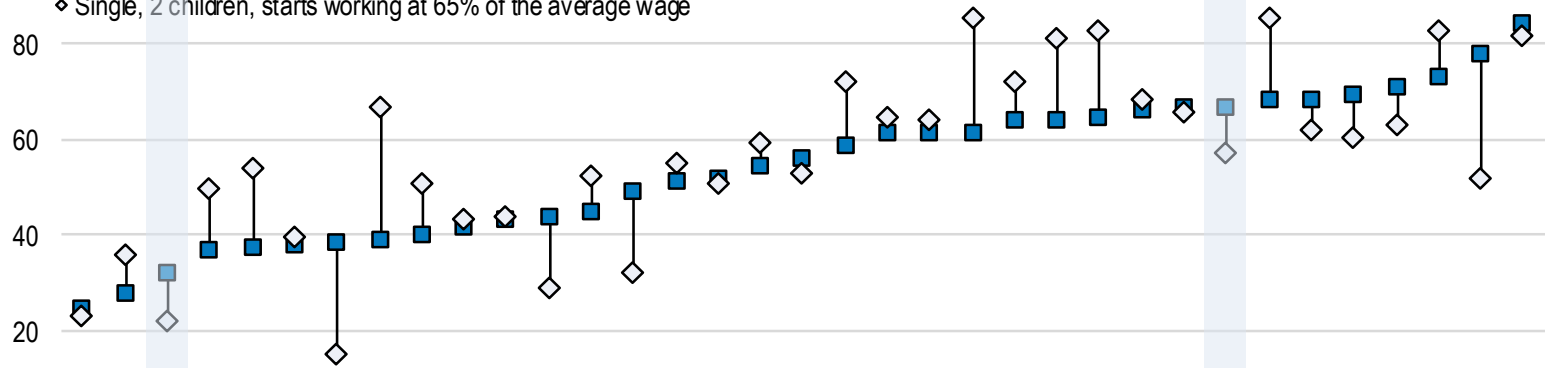

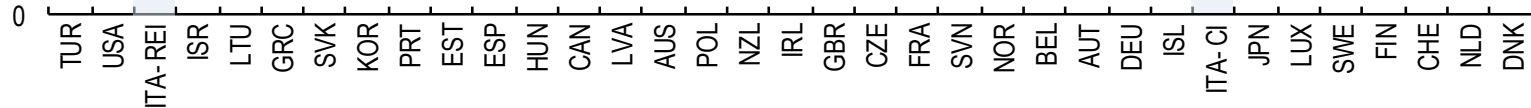

Note: The effective tax rate on entering employment measures the proportion of additional in-work earnings that is lost to higher taxes and lower benefits when a jobless person takes up employment at the indicated wage rates. "ITA- REI" shows the policy rules relating to the 2018 "Reddito di inclusione", the guaranteed minimum income implemented in 2018; "ITA- CI" reflects the Citizen's Income policy rules prescribed by the decree of January 2019. For other OECD countries, values reflect 2018 policies.

* In Panel A: the couple has 2 children. The "ITA-CI" value reflects both the REI and CI policy rules, as the net effective tax rate is the same under both.

Source: Calculations based on the OECD Tax-benefit model. 
8. A female second earner's decision to seek work are more sensitive to the net income they will earn than the primary earner's, and this relationship is particularly strong in Italy (Figure 2) (Colonna and Marcassa, 2015 [3]; Bargain and Peichl, 2013 [4]; Bargain, Orsini and Peichl, 2013 $\left.{ }_{[5]}\right)$. Nationally, employment rates of women in couples are low, and parttime employment rates are high. On the other hand, single women are more likely to be employed than the European average (OECD, 2019 ${ }_{[1]}$ ). As shown below (Figure 5 and Figure 7), the tax and benefit system limits the gains in disposable income for second earners from deciding to enter work or working more hours when they are paid at relatively low wage rates. This combines with the dearth of childcare places, which is especially pronounced in southern regions, to keep female employment rates low.

9. Italy's low employment rates and relatively high part-time work in lower-wage regions among women contribute more to the large disparities in incomes and well-being between regions than in most OECD countries. In most other OECD countries differences in productivity between regions play a much larger role in explaining differences in GDP per capita. Addressing the wide and persistent gap in employment rates between Italy's leading and lagging regions is essential to address enduring disparities in well-being (OECD, 2019 $\left.9_{[1]}\right)$.

\section{Developing a minimum income scheme in Italy}

10. Over recent years, introducing a guaranteed minimum income has become a priority of Italian governments (Sacchi, 2018 $8_{[6]}$ ), in line with OECD Survey recommendations (OECD, 2013 ${ }_{[7]}$; OECD, 2015 $[8]$; OECD, 2017 ${ }_{[9]}$ ). Guaranteed minimum income schemes act as last-resort safety nets for very low income and low wealth households. Design choices for guaranteed minimum income schemes centre on eligibility thresholds and transfer amounts, as well as the associated requirements of engaging in job-search, training, and other social programmes. In general, eligibility is conditional on income and assets being below certain thresholds. As guaranteed minimum income benefits are low and well below national poverty lines in most OECD countries, such schemes by themselves reduce the depth of poverty (i.e. the gap between their incomes and the poverty line), rather than lifting households out of poverty.

11. Employment is the best antidote to poverty (Causa, Hermansen and Ruiz, 2016 ${ }_{[10]}$ ). While the income transfers provided by guaranteed minimum income schemes can be effective in the short term in alleviating poverty, as a general rule there is a trade-off between the generosity of transfers and the incentive for beneficiaries to find work. To help beneficiaries move into employment, many guaranteed minimum income schemes require beneficiaries to actively seek work or take part in training or other social support programmes that will improve their ability to find work in the longer-term and limit how long recipients can receive income transfers. To ensure that work pays for recipients, some schemes reduce transfer amounts gradually as recipients start gaining employment income. To the same end, a growing number of OECD countries provide in-work benefits to top-up the incomes of low-wage earners.

\subsection{Italy has progressively introduced a guaranteed minimum income targeting poor households}

12. Italy has developed national income support programmes that target very low income households. In July 2018, it joined other EU countries and most other OECD countries in providing a nationwide guaranteed minimum income. The entire working-age population with incomes and wealth below certain eligibility thresholds became eligible to Inclusion Income Scheme (REI - Reddito di Inclusione). 
13. The REI follows two decades of tentative minimum income schemes in Italy (Box 1). Introduced in January 2018, the REI was initially only available to very low income families out of work and with dependent children. The REI's eligibility thresholds and transfer amounts were low relative to other countries' guaranteed minimum income schemes (Figure 3). It provided a small income for eligible recipients that reduces their depth of poverty- without lifting their income above the poverty line.

\section{Box 1. A short overview of the evolution of minimum income schemes in Italy}

Italy's first national guaranteed minimum income scheme, the Reddito Minimo di Inserimento (RMI), operated between 1999 and 2004 in around 300 municipalities mostly in the South. It guaranteed households a monthly income of EUR 270 (plus family allowances), if they participated in various programmes to support employability. The outcomes were patchy. In some municipalities, high rates of deprivation and of informal activity and difficulties in assessing applications led to high enrolment rates. Social inclusion and activation programmes in many municipalities were too weak to move beneficiaries out of the programme and into employment. The work disincentive of the income support combined with undeclared activity to limited exits from the programmes (OECD, 2003 ${ }_{[11]}$ ). After the RMI ceased, different regions and municipalities trialled various minimum income schemes. Their effectiveness varied, and their patchy coverage fell short of a national social safety net (Strati, 2009 $9_{[12]}$ ).

The REI replaced two other national second-tier safety net programmes: the Support for Active Inclusion (SIA Sostegno per l'Inclusione Attiva) introduced in 2017, which targeted workless households on very low incomes and young dependent children, and the Unemployment Allowance (ASDI - Assegno di Disoccupazione), introduced in 2014, a prototype unemployment assistance scheme for older workers with low incomes whose access to unemployment insurance had expired.

14. The REI's low eligibility thresholds and transfers limited its adverse effect on work incentives as few recipients were able to earn income from work and remain eligible for the programme (Figure 3). The REI transfer amount was reduced by one Euro for each additional Euro earned, meaning that the household's net income did not increase with higher employment income. However this only applied as long as the household was eligible to receive the REI, which would be the case for few households in work given the eligibility threshold of EUR 3000 per year adjusted for household size. For renters, work incentives under the REI were stronger, as they could deduct up to EUR 7500 per year of rental payments from their income in calculating their REI eligibility and transfer values.

15. REI beneficiaries were required to actively seek work or engage in training or social support programmes, which were tailored to the needs of the beneficiary household. This was intended to support beneficiaries' well-being and employability, and ensure they achieved sustained gains in income and well-being. These programmes could include requirements ranging from registering at the public employment service to ensuring that children attend school regularly. Municipalities' social services were responsible for administering the REI and tailoring social and inclusion programmes for each beneficiary, building on municipalities' existing social services capacity. This capacity varies considerably between regions, with municipalities' capacity weakest in areas with the greatest social protection needs and where employment opportunities are rarer (OECD, $\left.2019_{[1]}\right)$.

16. In April 2019 the government replaced the REI with the Citizen's Income (CI). Table 3 summarises the two programmes. The CI's design and potential effects are detailed below. 
Table 3. Italy's expanding guaranteed minimum income programmes

\begin{tabular}{|c|c|c|}
\hline & 1. 2018 Inclusive Income Scheme (REI) & 2. 2019 Citizen's Income \\
\hline Effective: & July 2018 to April 2019 & April 2019 (replaces the REI) \\
\hline Maximum transfers: & $\begin{array}{l}\text { Annual value: } 0.75^{*}(3000 * \text { Equivalence Scale - } \\
\text { Equivalised Household Income). } \\
\text { Single person: EUR } 187.50 \text { / month or } \\
\text { EUR } 2250 \text { / year. }\end{array}$ & $\begin{array}{l}\text { EUR } 500 \text { / month or EUR } 6000 \text { / year, scaled by household size. } \\
\text { In addition, renters may access up to EUR } 280 \text { / month against rental } \\
\text { costs; and residents of a mortgaged property EUR } 150 \text { / month against } \\
\text { their mortgage costs. These are not scaled by household size. }\end{array}$ \\
\hline $\begin{array}{l}\text { Scale to adjust base income } \\
\text { transfer and income eligibility } \\
\text { threshold for household size: }\end{array}$ & $\begin{array}{l}\text { Basic ISEE }{ }^{1} \text { scale: Household size to the power of } \\
0.65 \text {, with some specific adjustments in the case of } \\
\text { for household members who require greater care. } \\
\text { Scale capped at } 5 \text {. }\end{array}$ & $\begin{array}{l}1 \text { for the first adult, } 0.4 \text { for each additional household member aged } 18 \text { or } \\
\text { older and } 0.2 \text { for each additional child, to a maximum of } 2.1 \text {. }\end{array}$ \\
\hline Withdrawal rate: & $100 \%$ withdrawal rate against ISEE value & $\begin{array}{l}100 \% \text { withdrawal rate against initial total household income. } 80 \% \\
\text { withdrawal rate against additional household income gained after the } \\
\text { household starts receiving the Citizen's Income. }\end{array}$ \\
\hline Income eligibility definition: & $\begin{array}{l}\text { ISEE indicator below EUR } 6000 ; \text { Income } \\
\text { component of ISEE below EUR } 3000 \text {. }\end{array}$ & $\begin{array}{l}\text { Household income below EUR } 6000 \text {, scaled for household size, plus } \\
\text { EUR } 3360 \text { or EUR } 1800 \text { if eligible for rent or mortgage support. } \\
\text { ISEE value below EUR } 9360 \text {. } \\
\text { Abolishes ISEE EUR } 3000 \text { income eligibility requirement. }\end{array}$ \\
\hline Asset eligibility thresholds: & $\begin{array}{l}\text { Non-financial assets below EUR } 20000 \text { and } \\
\text { financial assets below between EUR } 6000 \text { and } \\
\text { EUR } 10000 \text {, depending on household size. No } \\
\text { household members with a registered vehicle or } \\
\text { boat in the previous } 24 \text { months. }\end{array}$ & $\begin{array}{l}\text { Value of real estate assets (excluding the main residence) below } \\
\text { EUR } 30000 \text {. Does not own a vehicle. Moveable property assets below } \\
\text { EUR } 6000 \text { for single persons, EUR } 2000 \text { more for additional family } \\
\text { members up to EUR } 10000 \text { and EUR } 5000 \text { more for each disabled } \\
\text { household member. }\end{array}$ \\
\hline Activity requirements: & $\begin{array}{l}\text { Must engage in customised programme of job } \\
\text { search, training or other social support. }\end{array}$ & $\begin{array}{l}\text { Beneficiaries either enter a work pact and work up to } 8 \text { hours per week on } \\
\text { municipal projects, or enter a social inclusion pact if unemployed for more } \\
\text { than } 24 \text { months and their public employment service councillor } \\
\text { determines that the applicants' needs are multi-dimensional. }\end{array}$ \\
\hline Residency requirements: & $\begin{array}{l}\text { Resident of Italy for at least } 2 \text { years at the time of } \\
\text { submitting application. }\end{array}$ & $\begin{array}{l}\text { Resident in Italy for at least } 10 \text { years, and continuously for the previous } \\
2 \text { years. }\end{array}$ \\
\hline Duration: & $\begin{array}{l}18 \text { months. Renewable for an additional } 12 \text { months } \\
\text { after } 6 \text { months' waiting period. }\end{array}$ & $\begin{array}{l}18 \text { months. Renewable for an additional } 18 \text { month periods after } 1 \text { month } \\
\text { pause. }\end{array}$ \\
\hline Interaction with other benefits: & $\begin{array}{l}\text { Unemployment Insurance (NASPI) recipients } \\
\text { cannot access the REI. They can claim the REI } \\
\text { three months after the UI has expired. } \\
\text { Non-contributory means tested benefits received } \\
\text { at the same time as the REI are not part of the } \\
\text { means test's income definition; these amounts are } \\
\text { subtracted from the final REI entitlements. }\end{array}$ & $\begin{array}{l}\text { Unemployment Insurance (NASPI) recipients can access the Citizen's } \\
\text { Income. } \\
\text { Non-contributory means tested benefits received are included in the } \\
\text { Citizen's Income means test. } \\
\text { Beneficiaries remain eligible for reduced electricity and gas tariffs. }\end{array}$ \\
\hline Penalties or sanctions: & $\begin{array}{l}\text { Benefit is reduced or withdrawn if the beneficiary } \\
\text { does not participate in the activities set out in the } \\
\text { programme. If a declared beneficiary's income is } \\
\text { inconsistent with their actual income, then benefit } \\
\text { may be reduced or withdrawn and a fine imposed } \\
\text { if they would not be eligible for the benefit. }\end{array}$ & $\begin{array}{l}\text { Benefit is reduced or withdrawn if the beneficiary fails to comply with the } \\
\text { employment or social inclusion pact. Criminal penalties, including } \\
\text { imprisonment for } 1 \text { to } 6 \text { years, for presenting false statements or } \\
\text { documents or omitting to provide or update information that relates to } \\
\text { eligibility and benefits. }\end{array}$ \\
\hline Tax treatment: & Not taxable & Not taxable \\
\hline
\end{tabular}

1. The INSEE is Italy's equivalent economic situation indicator' composite measure of household income and assets, adjusted for the number and characteristics of household members. See Notes to Table 1 and Box 1.4 in $($ OECD, 2019[1]) for further details.

\section{Assessing the Citizen's Income and two hypothetical tax and benefit policy reforms}

17. This section compares the CI scheme and two hypothetical tax and benefit policy reforms with Italy's tax benefit policies operating at the end of 2018, when the REI was operating. Table 2 summarises the alternative policies.

18. Reforming tax and benefit policies has diverse immediate and longer-term effects on households' incomes and work incentives, social and regional disparities, and public finances. The interactions of tax and benefit rules across different household structures and 
labour market situations makes these effects complex. To stimulate and summarise these effects, this paper uses a suite of complementary models:

- The OECD's tax-benefit model (TaxBEN) enables analysis of the effects of tax and benefit policies on a given working-age household's net income (OECD, 2019, forthcoming $\left.{ }_{[13]}\right)$. Box 2 summarises the key OECD tax-benefit policy indicators. The model incorporates the tax and benefit policy rules that apply to working age households for OECD and several non-OECD countries from 2001 to 2018. The model simulates income generated from employment, taxes and benefits such as family benefits, unemployment benefits, or cash benefits for rented accommodation, given the household's situation. Families are assumed to have no or so few assets such that assets do not affect their tax-benefit position. The model allows for comparisons of net income and its components across different household compositions, and different labour market statuses and wage levels of each household member. It also allows comparisons of different policy scenarios. TaxBEN is a static simulation tool, which accounts for the direct effects of policies holding household behaviour and household structure constant, rather than accounting for the effect of policies on behavioural decisions.

- The EUROMOD model also applies a country's tax and benefit policies to simulate the net income of households given their composition and labour market activity (Sutherland and Figari, 2013 ${ }_{[14]}$ ). EUROMOD aggregates these household-level outcomes using representative household survey data of the population structure, activity and market income distribution. The model estimates the effect of policy changes on public expenditures and revenues, on net income across regions or population subgroups, and on overall poverty and inequality. Like TaxBEN, EUROMOD is a static microsimulation model - it holds the composition, characteristics and behaviour of households constant, rather than allowing for change in response to policy reforms. It therefore represents the direct effects of policy shifts.

- The OECD's long-term cross-country macroeconomic models generate estimates of the longer-run effects of tax and benefit policy reforms on employment and productivity and allow for households' behaviour to adapt to policy reforms (Guillemette and Turner, 2018 ${ }_{[15]}$ ). These models incorporate summary indicators of the effects of the various tax and benefit policies on personal income tax rates and wedges at specific wage levels and household types, family benefit spending, and overall income inequality. The models generate estimates of the relationship between these indicators and employment rates among primary and secondary earners, productivity growth and overall activity. 


\section{Box 2. Tax and benefit policy outcomes and indicators}

The OECD TaxBEN model calculates tax liabilities and cash benefit entitlements for different family and labour-market situations. The main measures of the effects of policy rules on household income are:

- Net household income: The household's disposable income from employment wages (if any) after tax payments and transfer receipts.

- Effective tax rate on increasing hours or wage rate, or 'marginal effective tax rate' (METR): The fraction of a small increase in gross earnings that is "taken away" through higher taxes and lost benefits. The METR is computed by dividing the increase in taxes and the reduction in benefits (generated by the increase in gross earnings) by the increase in gross earnings. The METR shows the financial incentive to earn more, for example by increasing working time. As the METR rises the worker will retain a smaller and share of the increase in gross earnings. This means that the higher the METR, the lower the incentives to work longer hours or seek a better-paying job.

- Effective tax rate (ETR) on entering employment, also known as 'participation tax rate': The fraction of additional gross earnings that is "taken away" through higher taxes and lost benefits on entering employment, from receiving unemployment benefits and guaranteed minimum income benefits, given the household's other characteristics and the wages that the household could earn.

Families are assumed to have no income sources other than cash benefits and/or employment income. It is assumed that the family possesses no or negligible assets and that there is no income from capital. In-kind benefits, such as school meals, retirement, sickness and disability benefits, and indirect tax payments are not considered. When taxes and benefits vary by region as a result of local autonomy in setting regulations TaxBEN uses a 'representative' region (the Lazio region in the case of Italy). When regional variations consist of deviations from general national regulations, which would otherwise apply, TaxBEN uses the national regulations.

Source: OECD (2019, forthcoming $[13])$

\subsection{The Citizen's Income raises support for low-income families but weakens work incentives}

19. The Citizen's Income (CI, "Reddito di Cittadinanza") is a guaranteed minimum income scheme that replaced the REI from April 2019. Table 3 summarises the transfers and eligibility rules of both schemes. The CI supplements a household's employment income, to ensure that the household's total income reaches the minimum of EUR 6000 per annum or EUR 500 per month for a single-person household, scaled higher for larger households. There are additional transfers for households who rent or pay a mortgage for their primary residence. Households with a disabled member receive an additional allowance. Only households with income and assets below prescribed thresholds and who meet other behavioural and residency criteria are eligible for the CI (Table 3). The CI runs for renewable 18-month "labour inclusion pacts" or "social inclusion pacts". These are based on job activation programme participation and compulsory work schemes or participation in multidimensional social support activities.

20. Because of its high level and stringent eligibility criteria, the CI creates strong disincentives for members of low income households to enter employment or to increase their employment incomes by working longer hours (Figure 5 and Figure 7). When a single individual is assessed for the $\mathrm{CI}$, their transfer amount is calculated so they reach the target minimum income (EUR 6000 per annum for a single person). The transfer tops up any earned income below that threshold, meaning that it is withdrawn at a $100 \%$ rate. For 
example, a beneficiary working longer hours to raise her income but still earning less than EUR 6000 annually receives a lower CI transfer than one earning a lower income, and both beneficiaries' net income would be EUR 6000.

21. Households who rent or who pay a mortgage on their principal residence receive additional support of up to EUR 3360 per year (EUR 280 per month) for rent or EUR 1800 (EUR 150 per month) for mortgage payments. These amounts are not scaled by household size, meaning that larger households receive substantially less support per person than smaller households. Most OECD countries provide some scaling for larger households for housing cost support.

22. For households where all members are older than 67, a parallel programme, the Citizen's Pension provides EUR 7560 (EUR 630 per month) for a single person who owns their residence, EUR 130 per month more than for equivalent working-age individual. This programme uses the same equivalence scaling for household size as the CI.

23. The CI transfers for single or two-person households that are eligible for the rent or mortgage allowances are more generous than the REI and most other OECD countries' guaranteed minimum income schemes. For these households, transfers are near the OECD relative poverty lines of $50 \%$ of the median income (Figure 3) and are above Italy's absolute poverty lines for households living in southern regions outside of metropolitan centres (Table 4). For larger households, the transfers are more typical of other OECD countries compared with the national median wage (Figure 3).

24. Figure 6 shows the evolution of the net income (black line) and its components - i.e. gross wages, taxes and transfers - as the principal earners' gross earnings (expressed as percentage of average wage) increase. It presents different panels for different family types and different policy scenarios. It illustrates how income taxes and different benefits contribute to net incomes of selected household types under different policy scenarios. A net income line that stays flat as the principal earner's gross income increases indicates weak incentives to earn more as gains in gross earnings are offset by higher taxes or lower benefits. Figure 6, Panel B, shows that this is the case with the CI.

25. According to the CI rules, if a household receives the transfer, and later a household member starts working or earning more, then the CI transfer is reduced by $80 \%$ of the additional household income for the remaining period of the labour inclusion pact. Once the labour inclusion pact expires and the household reapplies for the CI, the CI transfer is recalculated considering the current household income (i.e. the transfer is reduced by $100 \%$ of the additional household income). This results in a net income (solid back line in Figure 6, Panel B) that remains constant at EUR 14160 as gross earnings rise up to the equivalent of EUR 10600 for a single-earner households with 2 children. This implies a $100 \%$ marginal effective tax rates at low wages or short hours. This rate is among the highest across OECD countries (Figure 7). Moreover, this marginal effective tax rate does not account for the additional costs that the household would incur as they start working, such as caring for dependent children or other relatives. This creates disincentives and risks working against the Cl's objectives of encouraging low-income households to enter the formal labour market or to increase their employment income, which are the best means of achieving a sustained movement out of poverty. 
Figure 5. The Citizen's Income raises the effective tax rates on entering employment at low wages, weakening incentives to enter formal employment

Effective tax rate on entering employment at various wage levels, expressed as $\%$ of average wage

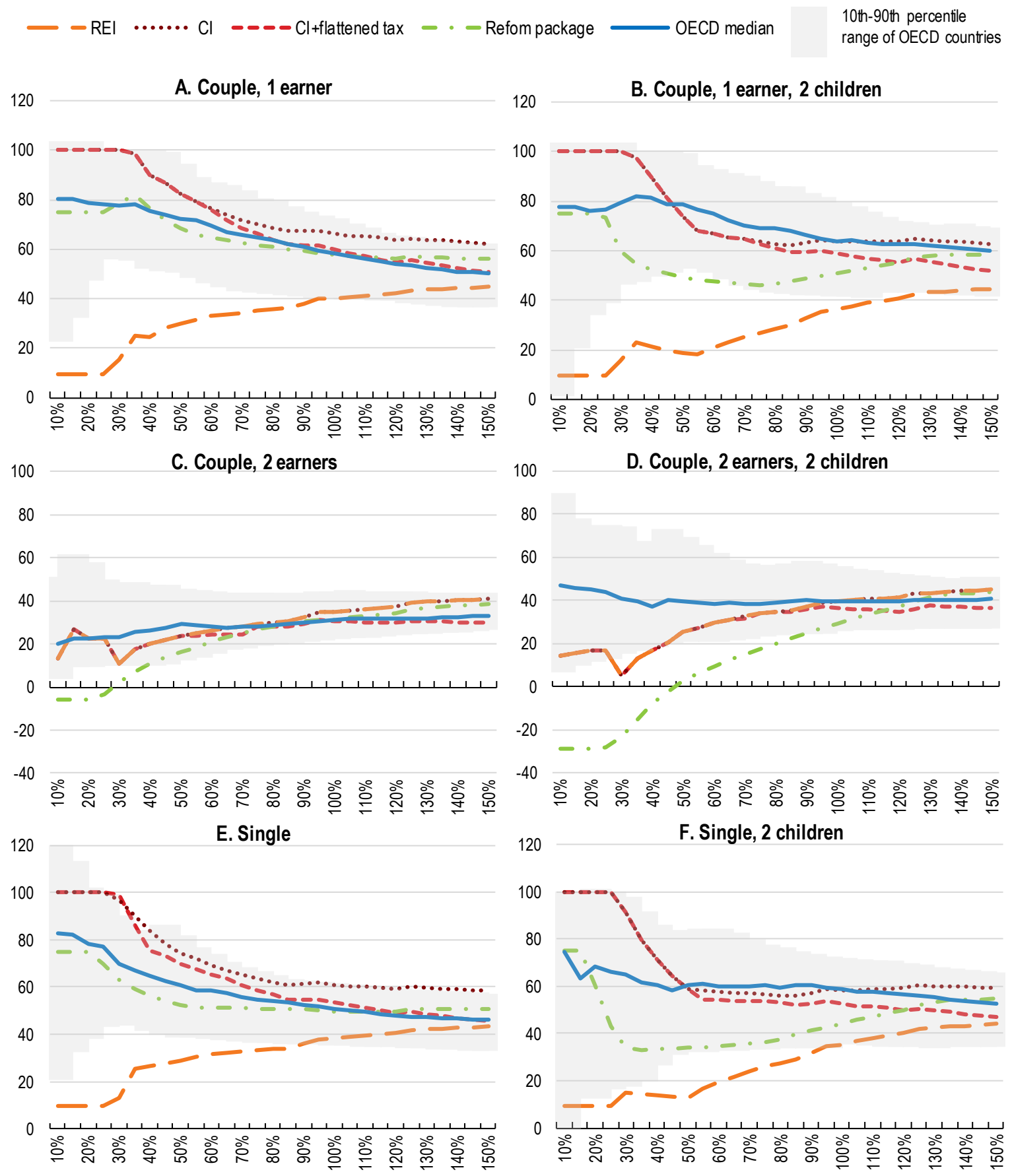

Note: The effective tax rate on entering employment measures the proportion of in-work earnings that is lost to higher taxes and lower benefits when a jobless person takes up full time employment at various wage rates, expressed as a percent of the average wage on the horizontal axis. "REI" shows the policy rules relating to the 2018 "Reddito di inclusione", i.e. the guaranteed minimum income programme implemented in 2018; "CI" reflects the Citizen's Income policy rules prescribed by the decree of January 2019; "CI + flattened tax" includes the flatter personal income tax rates scenario described in Table 9, and "Reform package" reflects the policy rules relating to the hypothetical proposed policy package proposed in Table 10. For other OECD countries, values reflect 2018 policies. In the 2 earner couple, 1 earner is assumed to earn $50 \%$ of the average full-time wage.

Source: Calculations based on the OECD Tax-benefit model. 
Figure 6. The Citizen's Income introduces a floor for households' incomes Contributions of gross earnings, benefits and taxes to net income under alternative policies, Euros

Couple, 1 earner, 2 children

\section{A. Reddito d'inclusione (REI, 2018)}
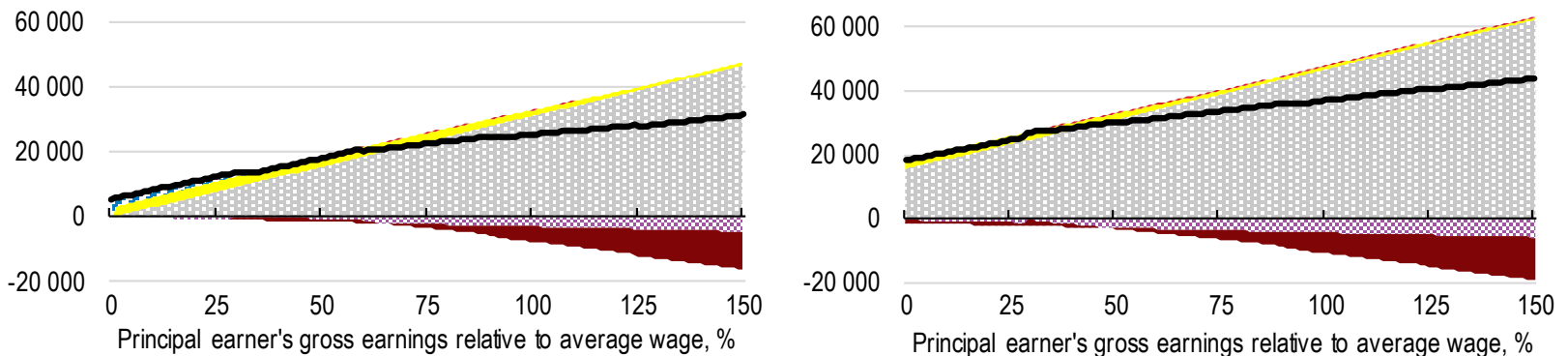

B. Citizen's Income
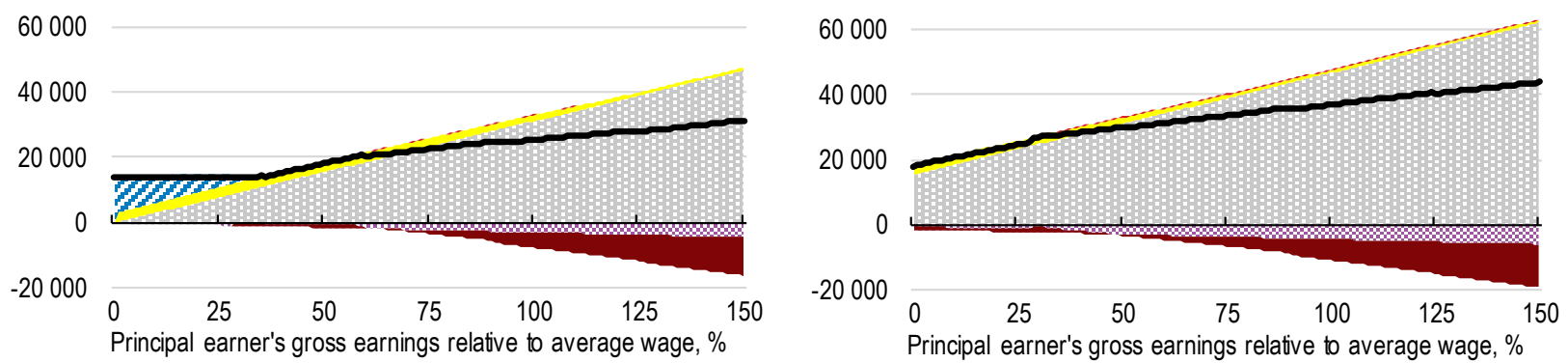

C. Citizen's Income and hypothetical flattened income tax schedule
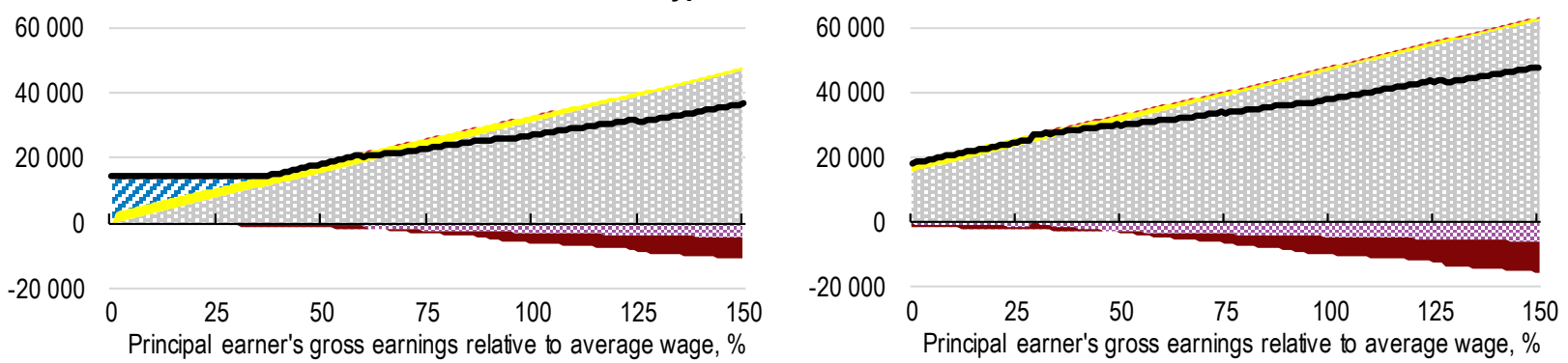

D. Reform package of low-wage in-work benefits, guaranteed minimum income, and simplified personal income tax system
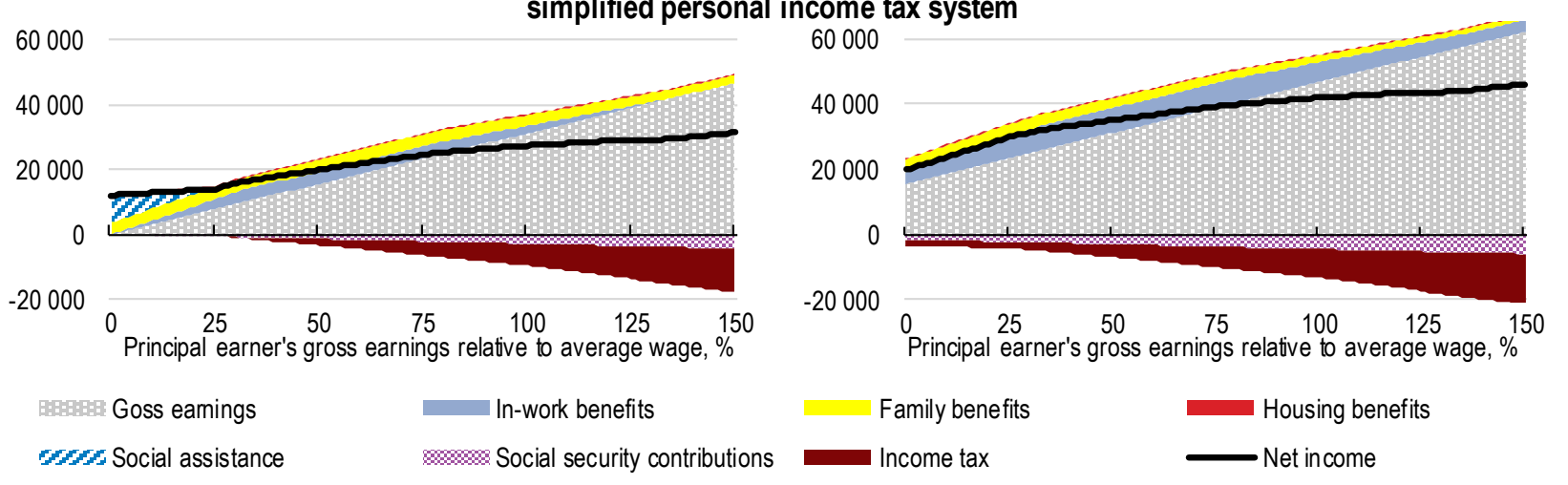

Income tax $\quad$ Net income 
Couple, 1 earner, 0 children

Couple, 2 earners, 0 children

A. Reddito d'inclusione (REI, 2018)
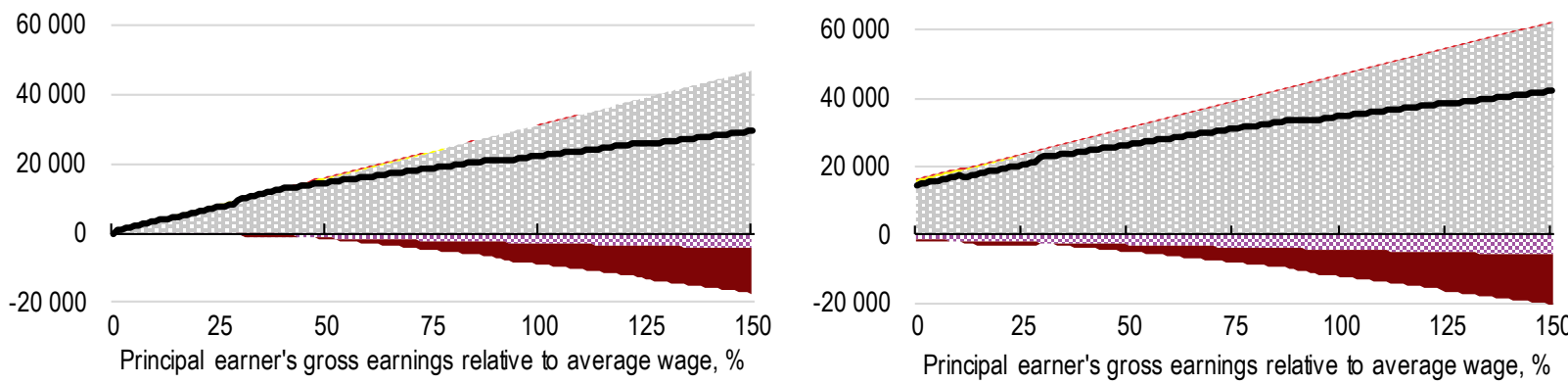

\section{B. Citizen's Income}
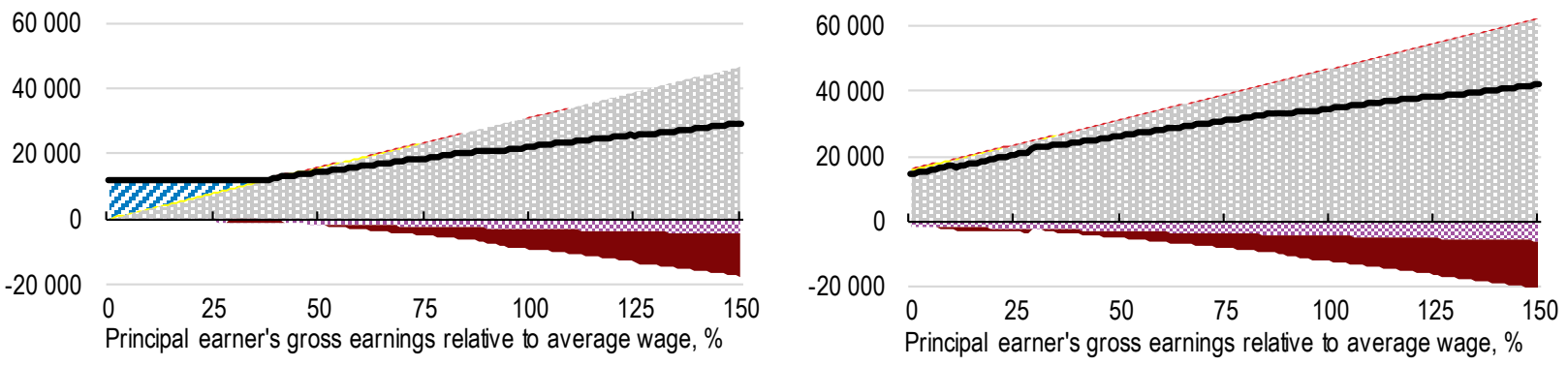

C. Citizen's Income and hypothetical flattened income tax schedule
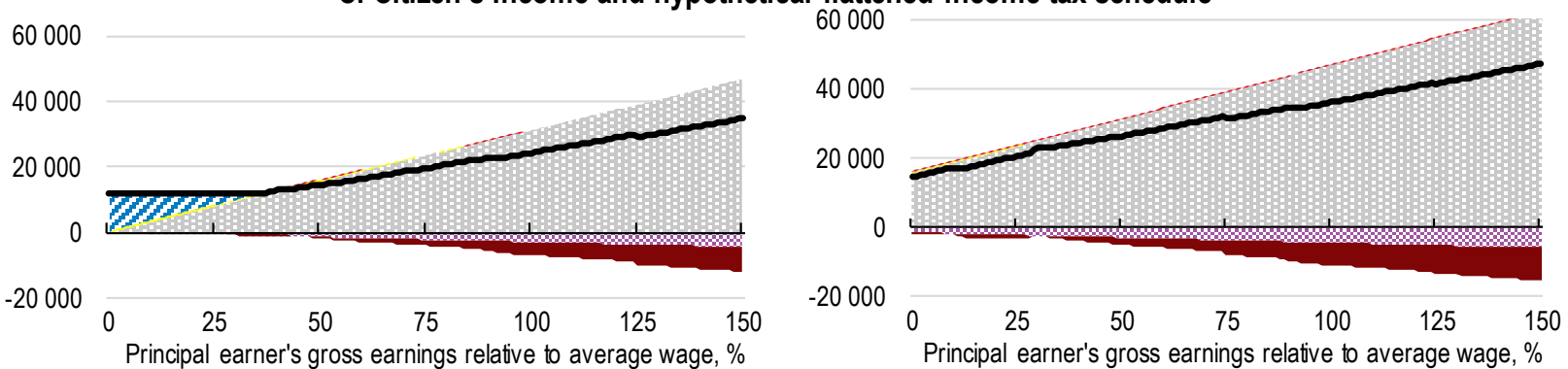

D. Reform package of low-wage in-work benefits, guaranteed minimum income, and simplified personal income tax system
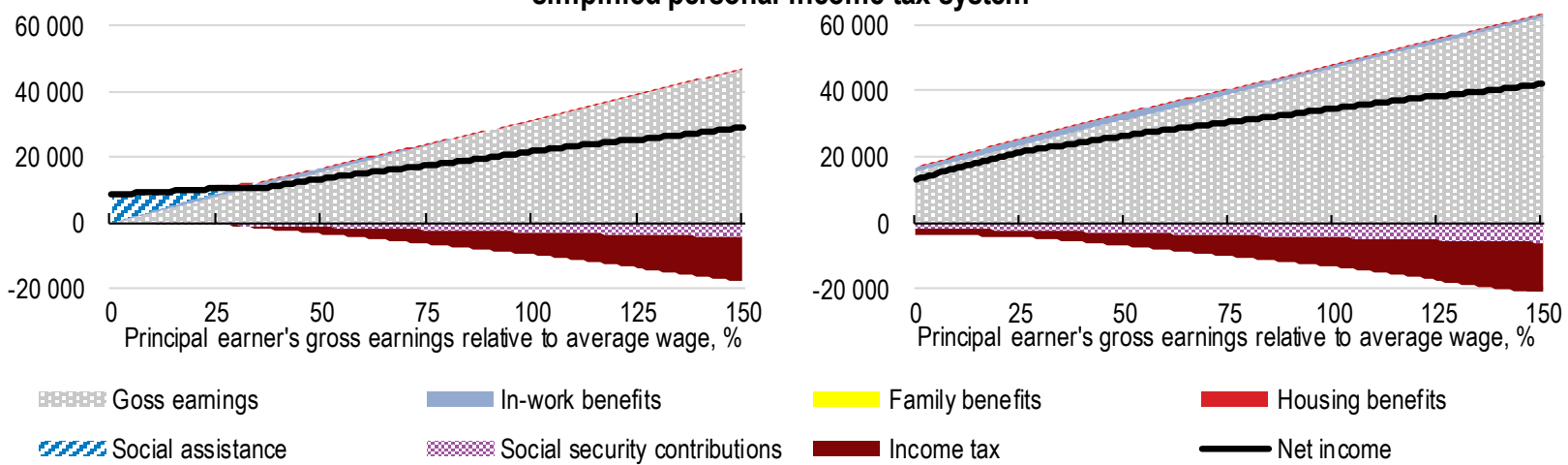
Family benefits
Housing benefits
Income tax
Net income

rys Social assistance

wawax Social security contributions 
Single, 0 children

A. Reddito d'inclusione (REI, 2018)

\section{Single, 2 children}

60000

40000

20000

0

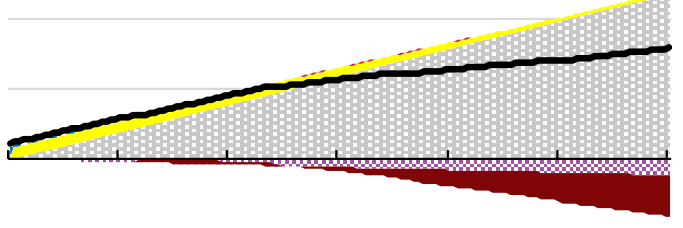

$-20000$

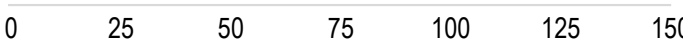

Principal earner's gross earnings relative to average wage, $\%$

Principal earner's gross earnings relative to average wage, $\%$

\section{B. Citizen's Income}
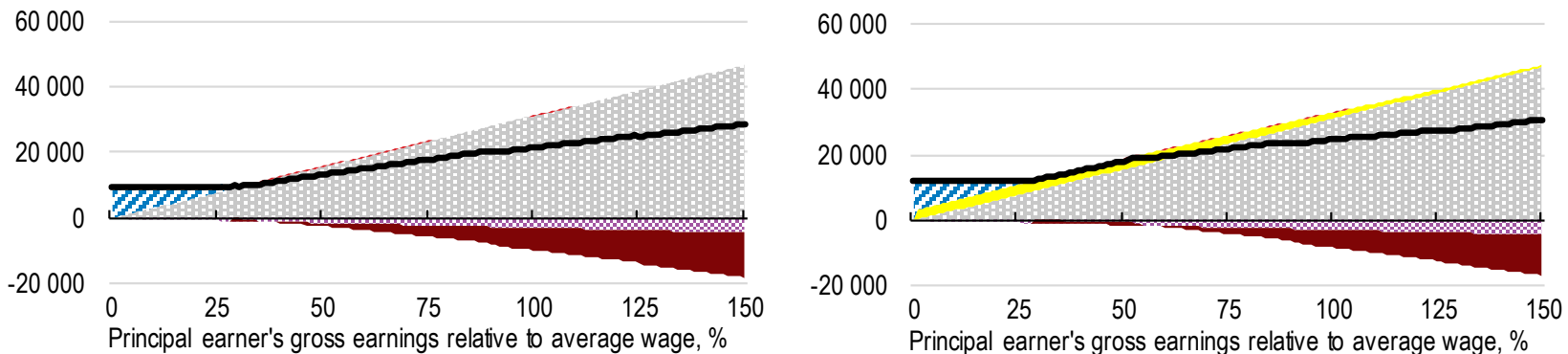

\section{Citizen's Income and hypothetical flattened income tax schedule}

60000

60000

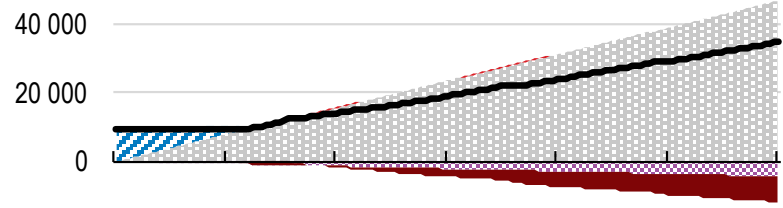

$-20000$

$\begin{array}{lrrrrrr}0 & 25 & 50 & 75 & 100 & 125 & 150 \\ & \text { Principal earner's }\end{array}$

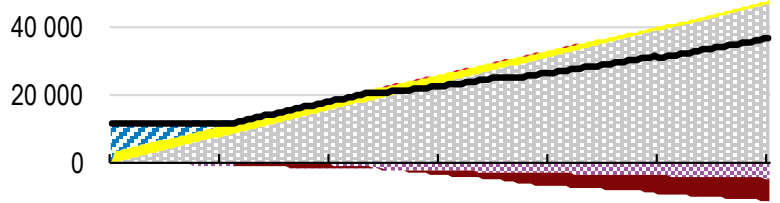

$-20000$

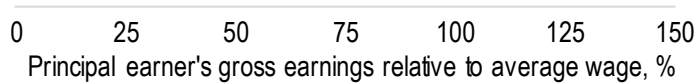

D. Reform package of low-wage in-work benefits, guaranteed minimum income, and simplified personal income tax system

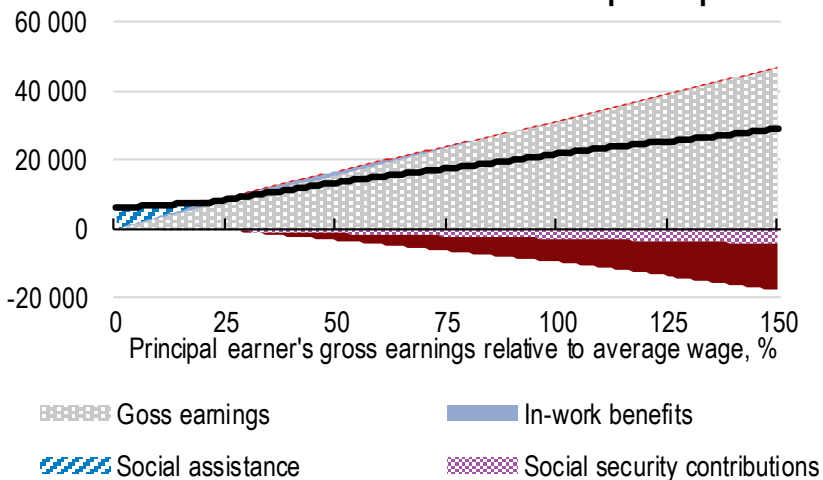
60000

40000

20000

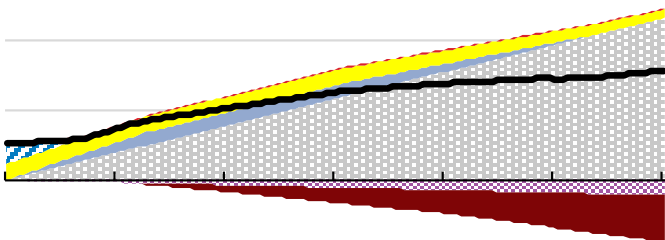

$-20000$

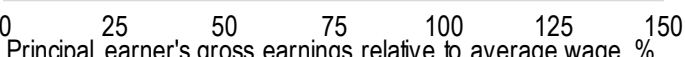

Family benefits

Housing benefits

Income tax Net income

Note: These graphs show the contribution to net income of employment earnings, benefits, taxes and social security contributions at various percentages of the average wage. The solid black line shows the final net or 'take home' income. Each row shows the results under a set of policy rules. The columns compare the situation of different household types. The second earner is assumed to earn $50 \%$ of the average wage. The household is assumed to pay a rent of EUR 6200 / year. The ISEE indicator used for the current REI takes into account the ISEE 'rent' and the 'earnings-related' deductions provided in the ISEE law.

Source: Calculations based on the OECD Tax-benefit model. 
Table 4. The rent and mortgage allowances raise the Citizen's Income for single person households above some poverty lines

Annual values, Euros

\begin{tabular}{|c|c|c|c|c|c|c|c|c|c|}
\hline \multirow[b]{3}{*}{$\begin{array}{l}\text { Household } \\
\text { type }\end{array}$} & \multicolumn{4}{|c|}{$\begin{array}{c}\text { Guaranteed minimum income anti-poverty } \\
\text { programmes }\end{array}$} & \multicolumn{5}{|c|}{ Poverty lines } \\
\hline & \multirow[b]{2}{*}{$\begin{array}{c}\text { REI } \\
(2018)\end{array}$} & \multirow[b]{2}{*}{$\begin{array}{l}\text { Citizen's } \\
\text { Income }\end{array}$} & \multirow{2}{*}{$\begin{array}{l}\text { Citizen's } \\
\text { Income } \\
\text { incl. } \\
\text { mortgag } \\
\text { e } \\
\text { support }\end{array}$} & \multirow[b]{2}{*}{$\begin{array}{l}\text { Citizen's } \\
\text { Income } \\
\text { incl. rent } \\
\text { support }\end{array}$} & \multirow[b]{2}{*}{$\begin{array}{l}\text { Eurostat } \\
60 \% \\
\text { median } \\
\text { income } \\
(2017)\end{array}$} & \multirow[b]{2}{*}{$\begin{array}{l}\text { OECD } \\
50 \% \\
\text { median } \\
\text { income } \\
(2017)\end{array}$} & \multicolumn{2}{|c|}{$\begin{array}{l}\text { ISTAT absolute consumption } \\
\text { poverty }(2017)^{*}\end{array}$} & \multirow[b]{2}{*}{$\begin{array}{l}\text { ISTAT } \\
\text { relative } \\
\text { poverty } \\
(2017)\end{array}$} \\
\hline & & & & & & & $\begin{array}{c}\text { South \& } \\
\text { islands, } \\
\text { municipalities } \\
\text { smaller than } \\
50000\end{array}$ & $\begin{array}{c}\text { North, } \\
\text { central } \\
\text { metropolita } \\
n\end{array}$ & \\
\hline Singe adult & 2250 & 6000 & 7800 & 9360 & 9925 & 8271 & 6730 & 9921 & 7814 \\
\hline $\begin{array}{l}2 \text { adults and } \\
2 \text { children } \\
\text { under } 14\end{array}$ & 5535 & 10800 & 12600 & 14160 & 20843 & 17369 & 13401 & 20962 & 21227 \\
\hline
\end{tabular}

Note: The Eurostat, ISTAT and OECD relative poverty lines do not include the cost of housing in the measure of income. The ISTAT absolute poverty line includes an allowance for housing costs. The absolute poverty line depends on the household members' ages, the macro-region and the municipality type.

Source: ISTAT; Eurostat; and OECD 2018 Tax and benefits database.

26. To be eligible for the CI, the household's income, moveable and real assets, and their Equivalised Economic Situation Index (ISEE) value must be below certain thresholds (Table 3). The ISEE value summarises the household's total income and assets, adjusted for the size and characteristics of the household (discussed in OECD $\left(2019_{[1]}\right)$ ). Both total household net income, equivalised for household size, and the ISEE value must be below EUR 6000 if the household is an outright owner of their residence, or EUR 9360 if the household rents their residence. Over 5 million individuals are likely to meet the income eligibility requirements, according to EUROMOD simulations using data from the 2016 European Union Statistics on Income and Living Conditions household survey. CI beneficiaries must provide correct information and up-to-date income and asset information, otherwise they may be required to retrospectively forfeit the benefit and may be punished by between 1 and 6 years' prison.

27. CI beneficiaries must reside in Italy for at least ten years, and continuously for the last two. This eligibility rule excludes recent Italian residents, despite this group's higher poverty rates and need for support to integrate in the labour market. This compares with the REI's two-year residency requirement, and between 2 and 5 year requirement in most other OECD members. The government estimates that this restriction excludes 86000 households who would otherwise be eligible given their low income and assets, reducing the expected CI expenditure by $6.7 \%$ or EUR 535 million (Commissione $11 \mathrm{a}$ del Senato della Repubblica, 2019 $[16])$.

\subsubsection{Citizen's Income transfers are less generous to larger households}

28. Larger households' CI transfers and income eligibility thresholds are scaled higher, by a factor of 0.4 for each additional adult and 0.2 for each child younger than 18 , up to a maximum of 2.1. This scaling factor is smaller than is commonly used to assess the additional needs of larger households (Table 5). The ISEE formula provides a more generous equivalence scaling for larger households than the CI's equivalence scale. The ISEE scale is also open-ended. This means that a larger household would receive a smaller CI transfer per euro of their ISEE value than an otherwise identical smaller household. Capping the CI equivalence scale at 2.1 means that CI transfers and income eligibility 
thresholds do not increase for households larger than, for example, 2 adults and 3 children, or 3 adults and 2 children. Reflecting this scaling, CI beneficiaries are more likely to live in smaller households compared with the corresponding general population, even though larger households are at greater risk of poverty than small households.

29. The low scaling for larger households may encourage households to split, at least for the purposes of their CI applications. In Greece, which introduced in 2017 a guaranteed minimum income programme similar in many respects to the Citizen's Income, 10 percentage points more single-person households applied for the benefit than in the underlying population, suggesting that households split. Greece's scheme scales benefits with the Eurostat equivalence scale, which is not capped and somewhat more generous to larger households than Italy's CI. Greece's experience suggests first that applications from single-person households need careful verification, and second that benefit parameters should be less generous to single households, for example by lowering the transfer amount, and more generous to larger households, through higher scaling, to discourage households from splitting (Marini et al., 2019 $\left.{ }_{[17]}\right)$.

\section{Table 5. The Citizen's Income equivalence scales penalise large households} Equivalence scales for household size, ratio to a single person household

\begin{tabular}{|l|c|c|c|c|c|}
\hline & ISEE* and REI & $\begin{array}{c}\text { OECD } \\
\text { ('Square root } \\
\text { Scale') }\end{array}$ & $\begin{array}{c}\text { Eurostat } \\
\text { ('OECD modified') }\end{array}$ & \multicolumn{2}{|c}{ Citizenship Income } \\
\cline { 2 - 6 } Overall rule & $\begin{array}{c}\text { Household size to } \\
\text { the power of } 0.65\end{array}$ & $\begin{array}{c}\text { Household size to the } \\
\text { power of } 0.5\end{array}$ & $\begin{array}{c}\text { 1 for household head, } 0.5 \text { for } \\
\text { each additional adult; } 0.3 \text { for } \\
\text { each child under } 14\end{array}$ & $\begin{array}{c}\text { 1 for household head, } 0.4 \text { for } \\
\text { each additional adult and } 0.2 \\
\text { for each additional child; } \\
\text { capped at 2.1. Rent costs not } \\
\text { scaled for ownership. }\end{array}$ \\
\hline 2 adults & 1.57 & 1.41 & 1.50 & 1.26 & 1.40 \\
\hline 2 adults +2 children & 2.46 & 2.00 & 2.10 & 1.51 & 1.80 \\
\hline 3 adults +2 children & 2.85 & 2.24 & 2.60 & 1.71 & 2.10 \\
\hline 2 adults +4 children & 3.20 & 2.45 & 2.70 & 1.71 & 2.10 \\
\hline
\end{tabular}

* In addition the ISEE equivalence scale provides allowances for certain household circumstances, such as single parents or disabled members.

Note: Results in the table refers to a jobless household without any other income sources. Where applicable, children are assumed to be younger than 14 .

Source: OECD calculations, OECD Tax and Benefits database, Eurostat.

\subsubsection{The Citizen's Income will reduce poverty but may entrench regional disparities in employment rates}

30. The CI will increase beneficiary households' net equivalised disposable income, especially in Southern regions (Figure 10). This can directly lead to a small fall in the poverty rate if eligible households take up the CI (Table 6), as the transfers will lift some recipients' incomes above the poverty line (Figure 3, Panel A). The CI has a larger impact on the poverty gap, reducing the difference between poor households' average incomes and the poverty line by $26 \%$. By raising the incomes of poorer households relative to other households, the CI transfers could reduce income inequality by $9 \%$ when measured by the quantile ratio (the ratio of income of the household at the $80^{\text {th }}$ to the household at the $20^{\text {th }}$ income percentile) (Table 6). This estimated impact only accounts for the CI's immediate effect on incomes, rather than the longer-term effects on households' incentives and ability to move into formal employment. 
Table 6. Effects of tax and benefit policy reforms on poverty, inequality and public expenditure

Change in indicator relative to baseline of 2018 policies

\begin{tabular}{|c|c|c|c|c|c|c|c|c|}
\hline \multirow[b]{2}{*}{ Scenario } & \multirow{2}{*}{$\begin{array}{c}\text { Fiscal impact } \\
\text { (change in revenues } \\
\text { less change in } \\
\text { transfers relative to } \\
\text { baseline, } \\
\text { EUR billions) }\end{array}$} & \multirow{2}{*}{$\begin{array}{l}\text { Poverty } \\
\text { gap index } \\
\text { (index poin } \\
\text { t change) }\end{array}$} & \multirow{2}{*}{$\begin{array}{c}\text { Poverty rate } \\
\text { (percentage } \\
\text { point change; } \\
\text { national relativ } \\
\text { e poverty line) }\end{array}$} & \multicolumn{2}{|c|}{ Inequality in disposable income } & \multicolumn{2}{|c|}{$\begin{array}{c}\text { Marginal effective tax rate } \\
(\%)^{2}\end{array}$} & \multirow{2}{*}{$\begin{array}{c}\text { Second earne } \\
\text { r effective tax } \\
\text { rate when } \\
\text { entering } \\
\text { employment } \\
(\%)^{3}\end{array}$} \\
\hline & & & & $\begin{array}{c}\text { Change in } \\
\text { Gini coefficient } \\
(0-100)\end{array}$ & $\begin{array}{c}\text { Change in } \\
\text { quantile ratio } \\
\text { (S80/S20) }\end{array}$ & $\begin{array}{c}67 \% \\
\text { average } \\
\text { wage }\end{array}$ & $\begin{array}{c}150 \% \text { average } \\
\text { wage }\end{array}$ & \\
\hline $\begin{array}{l}\text { Baseline level, end-2018 } \\
\text { policies: }\end{array}$ & -- & 5.5 & $13.5 \%$ & 31.5 & 5.62 & 39.1 & 53.7 & 29.2 \\
\hline $\begin{array}{l}\text { Replace REI with } \\
\text { Citizen's Income: }\end{array}$ & -5.2 & -1.4 & -0.4 & -0.8 & -0.50 & 39.1 & 53.7 & 29.2 \\
\hline $\begin{array}{l}\text { Replace REI with } \\
\text { Citizen's Income and } \\
\text { introduce hypothetical } \\
\text { flattened personal } \\
\text { income tax rates } \\
\text { Components: }\end{array}$ & -66.1 & \multirow[t]{3}{*}{-1.1} & \multirow[t]{3}{*}{0.7} & \multirow[t]{3}{*}{2.0} & \multirow[t]{3}{*}{0.25} & \multirow[t]{3}{*}{39.1} & \multirow[t]{3}{*}{27.2} & \multirow[t]{3}{*}{28.8} \\
\hline - Citizen's Income & -5.2 & & & & & & & \\
\hline $\begin{array}{l}\text { - Flattened personal } \\
\text { income tax rates }\end{array}$ & -60.9 & & & & & & & \\
\hline $\begin{array}{l}\text { Proposed reform } \\
\text { package: } \\
\text { Components: }\end{array}$ & -7.9 & \multirow{3}{*}{-1.5} & \multirow{3}{*}{-1.2} & \multirow{3}{*}{-1.2} & \multirow{3}{*}{-0.62} & \multirow{3}{*}{39.8} & \multirow{3}{*}{59.6} & \multirow{3}{*}{4.6} \\
\hline $\begin{array}{l}\text { - Low-wage in-work } \\
\text { benefits, guaranteed } \\
\text { minimum income and } \\
\text { reformed family } \\
\text { benefits }\end{array}$ & -19.2 & & & & & & & \\
\hline $\begin{array}{l}\text { - Simplified } \\
\text { progressive personal } \\
\text { income tax }\end{array}$ & 11.4 & & & & & & & \\
\hline
\end{tabular}

Notes: 1 . The poverty line is $50 \%$ of the median household disposable income, equivalised using the square root of the household size. 2. One-earner couple with two dependent children. The marginal effective tax rate is measured at income moving from $50 \%$ to $67 \%$ of the average wage, and $133 \%$ to $150 \%$ of the average wage. 3 . Two earner couple with two dependent children. Primary earner earns $67 \%$ of average wage. Second earner moves from no income to $50 \%$ of average wage. The EUROMOD simulations are based on a representative sample of the population, and households with all members aged 67 or older are assumed to receive the Citizen's Pension, if eligible.

Source: OECD calculations using EUROMOD (see source notes to Figure 8) and OECD Tax-benefit model.

31. The high effective tax rates on entering employment that the CI entails weaken work incentives and risk entrenching regional disparities in employment rates (Figure 5). A larger share of the population is eligible for the CI in southern regions, given the lower incomes. Weaker labour market and economic conditions make finding a formal-sector job more challenging in these regions. Further, beneficiaries may not be better off working as in the South many jobs pay less than the CI's benefits. The Social Security Institute (INPS) estimates that $45 \%$ of private sector employees in the South earn net labour income below the CI's transfers (Commissione 11a del Senato della Repubblica, 2019 [16]; Boeri, 2019 ${ }_{[18]}$ ). In addition, lower living costs in lagging regions extend the purchasing power of the CI transfers (Figure 8). All these factors may weaken incentives for CI beneficiaries to gain formal employment. 
Figure 7. Effective tax rates on increasing working hours are high in Italy Marginal effective tax rate, at various working hours expressed in $\%$ of full time work

$$
\begin{aligned}
& \text { - - REI .......... Cl ---.-Cl+flattened tax - - - Reform package — OECD median } \\
& \text { 10th-90th percentile range of } O E C D \text { countries }
\end{aligned}
$$

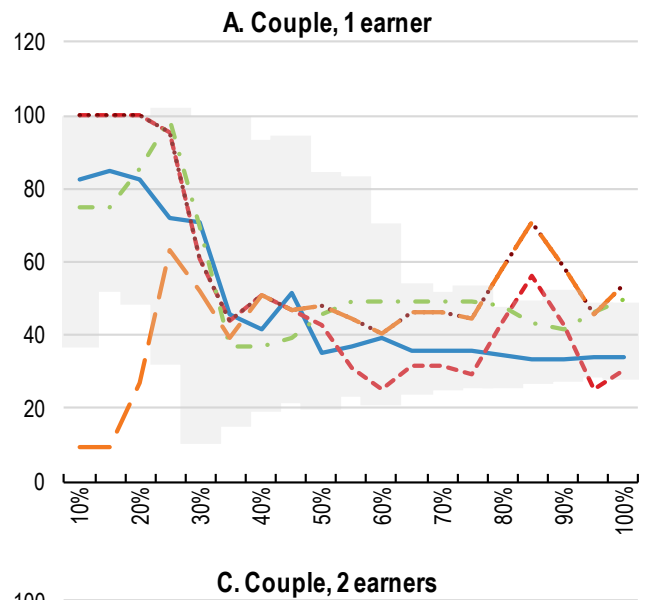

B. Couple, 1 earner 2 children
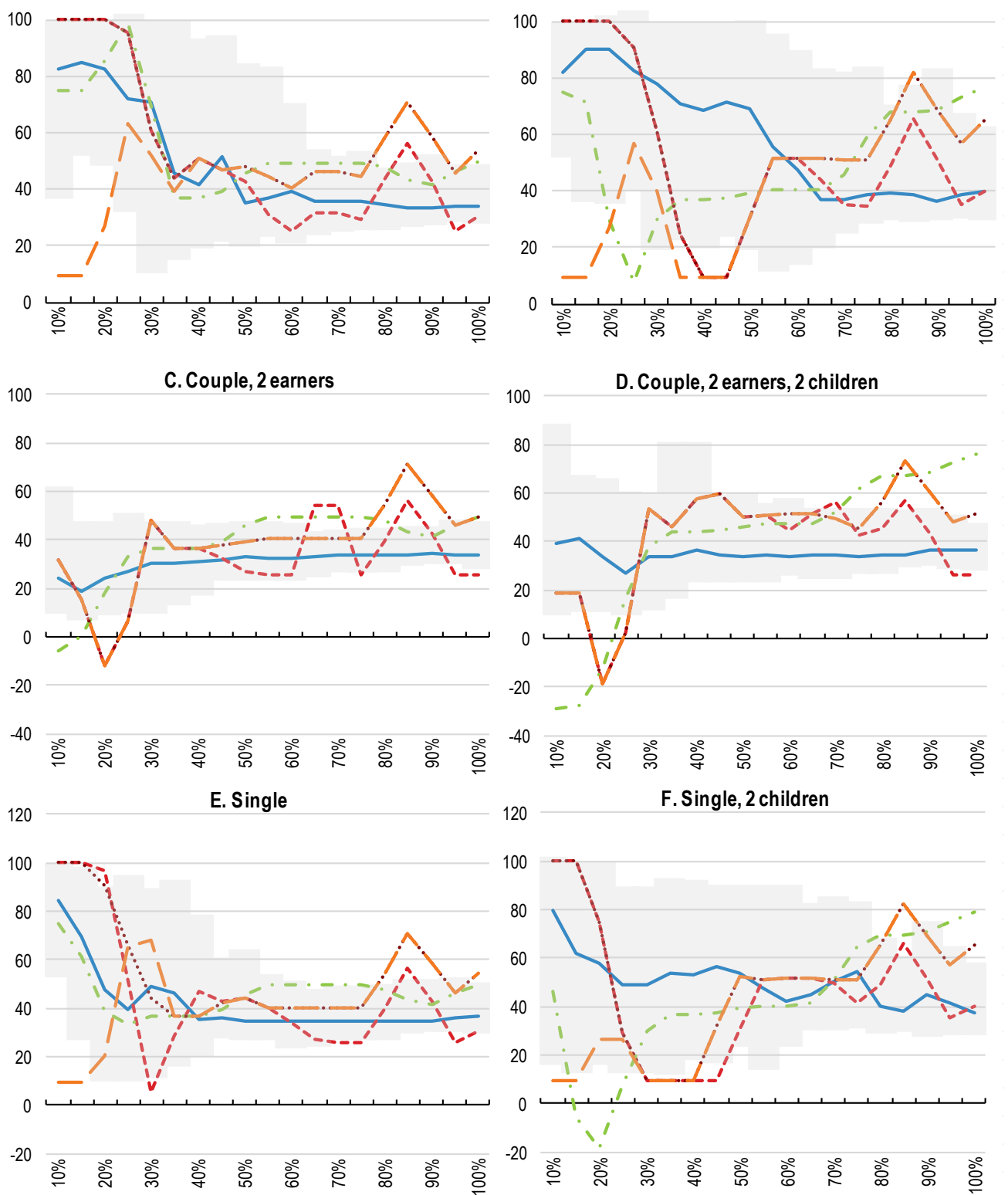

Note: The lines show the effective tax rate (ETR) when increasing working hours by 10 percentage points up to full time, for a person with a fixed hourly wage equal to EUR 31144 per year when working full time. Calculations do not consider any possible wage penalties when working part time. ETRs measures the percent of an increase in gross earnings that is lost in higher personal income tax and employee social security contributions and lower benefits. Results do not consider other financial costs that the household would face as the second earner starts working, such as childcare costs. "REI" shows the policy rules relating to the 2018 "Reddito di inclusione", i.e. the guaranteed minimum income programme implemented in 2018; "CI" reflects the Citizen's Income policy rules prescribed by the decree of January 2019; "CI + flattened tax" includes the flatter personal income tax rates scenario described in Table 9, and "Reform package" reflects the policy rules relating to the hypothetical recommended policy package proposed in Table 10. For other OECD countries, values reflect 2018 policies. In the 2 earner couple, 1 earner is assumed to earn $50 \%$ of the average full-time wage.

Source: Calculations based on the OECD Tax-benefit model. 
Figure 8. Households headed by the unemployed, sick or disabled and students particularly benefit from guaranteed minimum income policies

$\%$ change in net household equivalised disposable income, compared with end-2018 policies
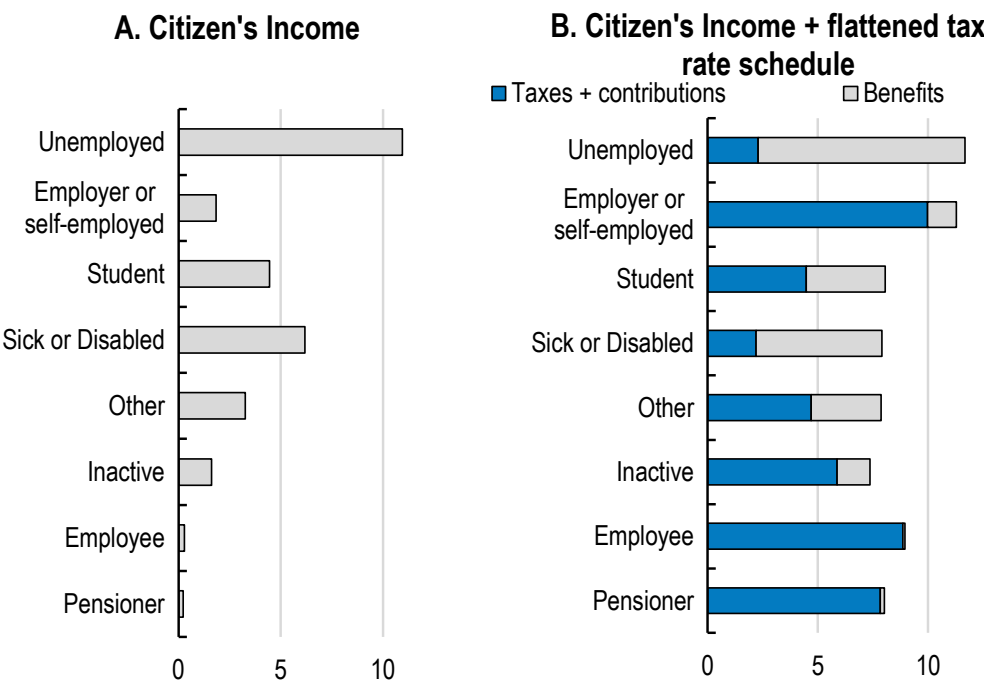

\section{Recommended reform package}

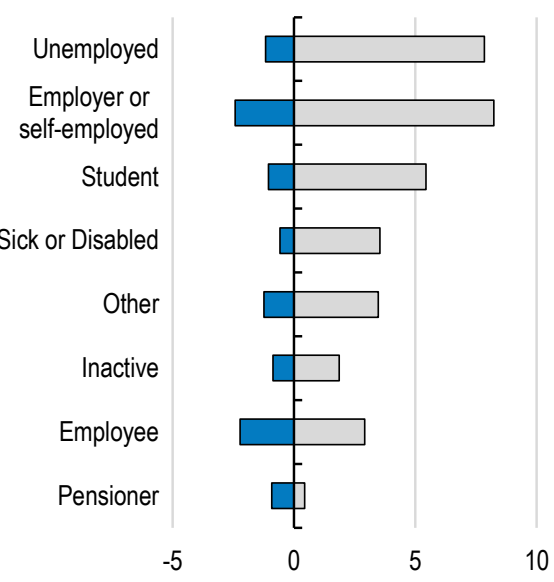

Note: The EUROMOD simulations include all population groups, and households with all members aged 67 or older are assumed to receive the Citizen's Pension if eligible.

Source: OECD calculations using EUROMOD, version I1.0+. EUROMOD is maintained, developed and managed by the Institute for Social and Economic Research (ISER) at the University of Essex, in collaboration with national teams from the EU member states. The European Union Programme for Employment and Social Innovation 'Easi' (2014-2020) financially supports extending and updating EUROMOD. The results and their interpretation are the authors' responsibility. The EUROMOD simulations presented here use the Italian version of the EU Statistics on Incomes and Living Conditions made available by Eurostat and ISTAT (166/2015-EU-SILC).

\section{Figure 9. Living costs are lower for low-income households in southern and rural areas}

Monthly cost of a set of goods and services at the poverty threshold for a family of 2 adults and 2 children, by geographical location, Euros, 2016

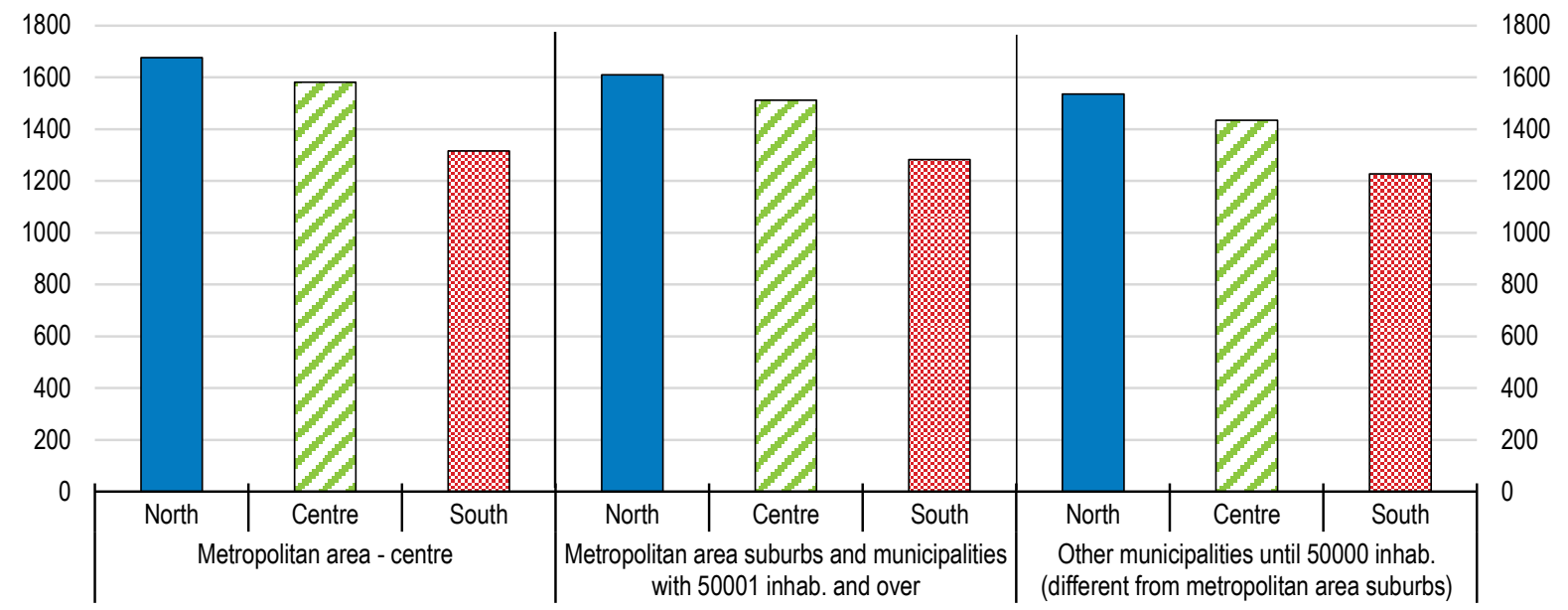

Note: One child is aged between 4 and 10 years and the other between 11 and 17 years.

Source: ISTAT 
Figure 10. Targeted income support is likely to particularly benefit residents of southern regions

$\%$ change in net equivalised disposable income, alternative policy reform scenarios
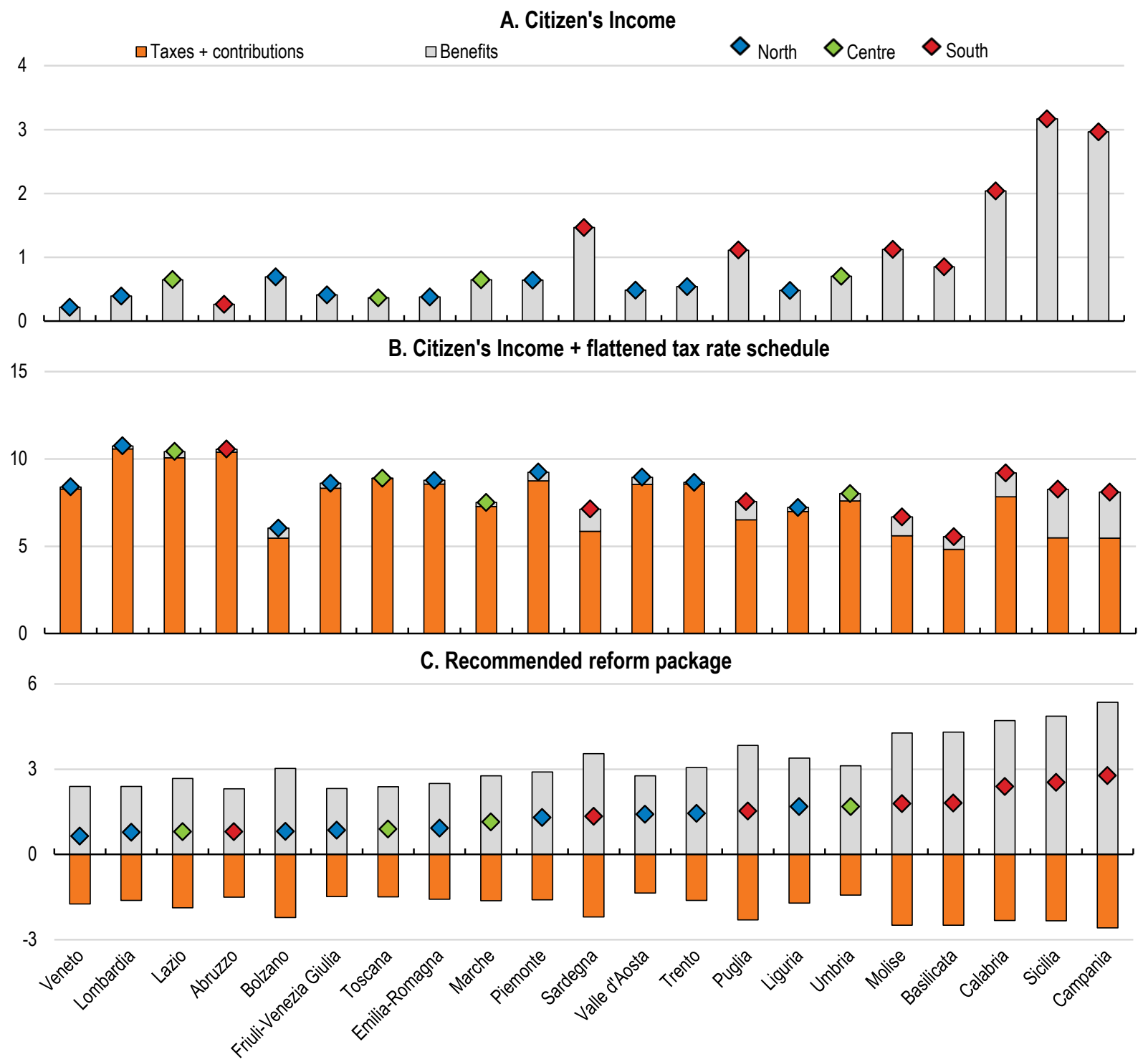

Note: The EUROMOD simulations include all population groups, and households with all members aged 67 or older are assumed to receive the Citizen's Pension, if eligible.

Source: OECD calculations using EUROMOD. See source notes to Figure 8.

\subsubsection{The Citizen's Income has little long-term impact on activity and public finances}

32. The 2019 Budget allocates EUR 6.0 billion or $0.26 \%$ of GDP to fund the CI from April 2019 and $0.31 \%$ of GDP over the following years. This cost estimate is consistent with OECD simulations using EUROMOD (Table 6). It is within the range of other European countries' guaranteed minimum income schemes (Baldini et al., 2018 $8_{[19]}$ ). For example, Greece's 2017 guaranteed minimum income, similar in many respects to the CI, is projected to cost near $0.4 \%$ of GDP when fully implemented (OECD, 2018 [20]; European Commission, 2018 $8_{[21]}$ ), while the REI, itself heavily expanded in July 2018, was allocated just $0.1 \%$ of GDP in 2018 (European Commission, 2018 [22]). 
33. The CI will operate for the full fiscal year only from 2020. The government expects the CI's cost to decline after 2021 as beneficiaries graduate out of the scheme and into employment. However, experience in Italy and elsewhere shows that awareness and participation in such schemes take time to grow. For example, in the early 2010s the municipality of Turin trialled a minimum income programme, and found that it reached less than two-thirds of the eligible population. A similar share of the anticipated eligible beneficiaries had taken up the REI by January 2019. More than a year after Greece's guaranteed income scheme was rolled out nationally, $60 \%$ of households in the poorest income decile had not applied (Marini et al., 2019 $[17]$ ). As the share of the target population that participates in the scheme rises, its cost will rise before any savings from beneficiaries graduating from the scheme start to kick in.

\section{Table 7. Guaranteed minimum income programme costs are limited compared with the large revenue loss from a flattened personal income tax rate schedule}

Billions of EUR and percent

\begin{tabular}{|c|c|c|c|c|}
\hline & \multirow{2}{*}{$\begin{array}{l}\text { Baseline } \\
\text { level }\end{array}$} & $\begin{array}{l}\text { Citizen's } \\
\text { Income }\end{array}$ & $\begin{array}{l}\text { Citizen's Income + hypothetical } \\
\text { flattened tax rate schedule }\end{array}$ & $\begin{array}{l}\text { Proposed reform } \\
\text { package }\end{array}$ \\
\hline & & \multicolumn{3}{|c|}{ Change from baseline level } \\
\hline Net budget effect & - & -5.2 & -66.1 & -7.9 \\
\hline Tax revenues: & 201.4 & 0.0 & -60.9 & 11.4 \\
\hline (\% change) & - & $(0.0)$ & $(-30.3)$ & $(5.6)$ \\
\hline $\begin{array}{l}\text { Final income and regional } \\
\text { tax receipts: }\end{array}$ & 175.6 & 0.0 & -60.9 & 11.4 \\
\hline Tax credits: & 13.2 & 0.0 & 0.0 & -13.2 \\
\hline Spouse & 3.4 & 0.0 & 0.0 & -3.4 \\
\hline Parents & 0.2 & 0.0 & 0.0 & -0.2 \\
\hline Children & 9.6 & 0.0 & 0.0 & -9.6 \\
\hline Total social transfers: & 323.0 & 5.2 & 5.2 & 19.2 \\
\hline (\% change) & - & $(1.6)$ & $(1.6)$ & (6.0) \\
\hline $\begin{array}{l}\text { Fiscal bonus/new in-work } \\
\text { benefit: }\end{array}$ & 7.8 & 0.0 & 0.0 & 15.9 \\
\hline Total family benefits: & 8.6 & 0.0 & 0.0 & 1.2 \\
\hline $\begin{array}{l}\text { Guaranteed minimum } \\
\text { income transfers: }\end{array}$ & 2.2 & 5.2 & 5.2 & 2.0 \\
\hline
\end{tabular}

Source: OECD calculations using EUROMOD. See source notes to Figure 8.

34. In the longer-term, the CI's effect on real GDP will be limited (Table). The positive effect CI will have on GDP through higher labour productivity (because of lower inequality) will be offset by fewer people working due to weaker work incentives. This makes it all the more urgent to improve job-search and training programmes (as discussed in the next section). As the $\mathrm{CI}$ is not projected to increase aggregate employment, it is also unlikely to contribute to public revenues and generate fiscal space. 
Table 8. Tax and benefit reforms need to support both employment and productivity to lift GDP growth in the long-term

Cumulative effect relative to baseline of end-2018 policies, percent

\begin{tabular}{llll}
\hline & $\mathbf{2 0 2 5}$ & $\mathbf{2 0 3 0}$ & $\mathbf{2 0 4 0}$ \\
\hline Employment & & & \\
$\quad$ Citizen's Income & $-0.2 \%$ & $-0.4 \%$ & $-0.4 \%$ \\
$\quad$ Proposed reform package & $1.0 \%$ & $2.6 \%$ & $3.3 \%$ \\
Capital stock & & & \\
$\quad$ Citizen's Income & $0.0 \%$ & $-0.1 \%$ & $0.0 \%$ \\
$\quad$ Proposed reform package & $0.3 \%$ & $1.3 \%$ & $3.5 \%$ \\
Labour productivity & & & \\
$\quad$ Citizen's Income & $0.1 \%$ & $0.2 \%$ & $0.4 \%$ \\
$\quad$ Proposed reform package & $0.2 \%$ & $0.3 \%$ & $0.6 \%$ \\
Aggregate real GDP & & & \\
$\quad$ Citizen's Income & $-0.1 \%$ & $-0.1 \%$ & $0.0 \%$ \\
$\quad$ Proposed reform package & $0.9 \%$ & $2.4 \%$ & $3.8 \%$ \\
Public revenues (change, in \% of GDP) ${ }^{1 .}$ & & & \\
$\quad$ Citizen's Income & $0.0 \%$ & $0.0 \%$ & $0.0 \%$ \\
$\quad$ Proposed reform package & $0.4 \%$ & $1.0 \%$ & $1.4 \%$ \\
\hline
\end{tabular}

Note: Simulations account for the long-run macroeconomic effects of the Citizen's Income policy package, and of the proposed reform package on disposable income inequality, on tax wedges at the average wage for singles and for couples with children, additional spending on active labour market programmes, and additional family benefits. They do not account for changes in pension and retirement policies.

1. The ratio of government receipts to trend GDP is assumed to be $44 \%$ in $2025,41 \%$ in 2030 and $38 \%$ in 2040.

Source: OECD simulations based on Guillemette and Turner $\left(2018_{[15])}\right.$.

\subsubsection{Activity requirements are intended to help beneficiaries into work but need effective administration}

35. CI beneficiaries will be required to complete an assessment of their needs and then to engage in 'pacts' for job search and training programmes or other social support programmes, depending on their circumstances. These requirements are similar to those of the REI and many other countries' guaranteed minimum income programmes. In addition, those able to work are required to participate in public and community projects ("lavori socialmente utili") one day per week. Failure to comply with these pacts may lead to sanctions that range in severity from the retrospective loss of benefits, to imprisonment. These requirements may go some way to counter the work disincentives discussed above.

36. Beneficiaries who are able to work must accept an acceptable job offer or they lose their CI benefit. An acceptable job offer is within 100 kilometres (or 100 minutes' travel of their residence) for the first offer, $250 \mathrm{~km}$ for the second offer, and anywhere in Italy for the third. To be acceptable, its wage rate must also be at least $10 \%$ more than their CI transfer value - i.e., EUR 860 per month in the case of a single person receiving the full rent allowance. This wage threshold may lead many CI beneficiaries to refuse job offers that are part-time or pay typical wages in lagging regions.

37. To be effective in relieving poverty and stimulate employment, guaranteed minimum income schemes should seek to ensure that beneficiaries receive effective job-search and training programmes in conjunction with income support. Engaging all eligible recipients, especially those with high needs, is a challenge for most social protection programmes especially when schemes are complex (Frazer and Marlier, 2009[23]). Attaching punitive conditions to welfare benefits discourages the households with the greatest need for income 
support and other social services from applying for or maintaining the benefit. Several assessments have found this to be the case for the UK's Universal Credit reforms over the 2010s, which consolidated social benefits into a programme focused on beneficiaries complying with strict behavioural conditions (Wright et al., 2016[24]; Work and Pensions Committee, 2018[25]). Highly vulnerable beneficiaries have greater difficulties both complying with job search, training and social engagement requirements and proving their compliance, increasing the risk of drop out or non-take-up (Crepaldi et al., 2017 [26]). Assessments of the UK reform found that the beneficiaries with the greatest needs (the homeless, and those with mental health issues or with poor literacy) to be least able to meet benefit conditions, most likely to be sanctioned for failing to do so, and suffer most from those sanctions, even while the benefit conditions can also help them improve their behaviour (Batty et al., 2015 [27]).

38. Italy's public employment services (PES) have the lead role in implementing the CI. The Italian PES capacity has historically been limited. It has played a smaller role in job matching compared with other OECD countries. Furthermore, PES have not previously administered broad social protection programmes such as the Citizen's Income. CI beneficiaries that enter an 'employment pact' and many entering a 'social inclusion pact' are required to engage with the PES. The PES will need to be able to monitor and report on CI beneficiaries' participation in their assigned programmes, in addition to taking action if beneficiaries do not meet their obligations. Italy counts 550 public employment service centres, which are managed by regional administrations. Many of these centres, especially in lagging regions, lack the staffing and organisational capacity to fill their core employment service function, or to administer a programme as complex as the CI. Recognising these needs, recent governments have allocated considerable additional resources to strengthen the PES's capacity, including EUR 950 million over two years in the 2019 budget. The increase in resources is welcome but needs to be supported by an effective reorganisation plan of public employment services (discussed in OECD (2019 [1])).

39. Providing accessible and quality employment services across the country, especially in lagging regions, can contribute to reducing disparities and improving labour market outcomes for all people, including those not eligible for the CI (OECD, 2018[28]). Employment service capacity could expand faster if private employment agencies can complement the PES' role in job matching. A trial programme provided job seekers with vouchers to use for employment services, including those provided by private agencies. The voucher's value reflected the difficulty for the job seeker to find work given their characteristics. The Citizen's Income rules restrict these vouchers to Citizen's Income beneficiaries, excluding other job seekers, such as unemployment benefit recipients, reducing their access to employment services. Continuing to provide unemployment benefit recipients with access to the vouchers would improve their prospects of finding work before their income and asset loss leaves them eligible for the CI.

\subsection{Flattening personal tax rates would sharply cut revenues and benefit high income households}

40. This sub-section analyses a hypothetical tax and benefit reform, which has been under discussion for some time in Italy. It proposes flattening the personal income tax rates. Progressive personal income taxes are a powerful instrument to achieve inclusive growth. In Italy, improving the incentives to work and to earn, particularly for people with lower skills and in lagging regions, requires changing tax rates and credits along with welldesigned benefit reforms. Italy's personal income tax rates are higher than most other OECD countries across the income distribution, and lowering them would bring Italy's tax schedules closer into line with other OECD countries. Proposals have circulated in recent 
years to simplify Italy's complex tax system (with multiple personal income tax rates, tax credits, allowances and transfers) into two tax rates, while allowing households that would be worse off under this system to apply the previous system's tax rates. Table 9 presents a hypothetical flatter personal income tax scenario and compares it with the 2018 system.

Table 9. Hypothetical flatter personal income tax scenario National personal income taxes, credits and allowances for employees

\begin{tabular}{|c|c|c|}
\hline Scenario & A. 2018 system & B. Hypothetical flattened income tax rates \\
\hline $\begin{array}{l}\text { Tax rate } \\
\text { schedule: }\end{array}$ & $\begin{array}{l}\text { Below EUR } 15 \text { 000: } 23 \% \\
\text { EUR } 15 \text { 000-EUR } 28 \text { 000: } 27 \% \\
\text { EUR } 28 \text { 000-EUR } 55 \text { 000: } 38 \% \\
\text { EUR } 55 \text { 000-EUR } 75 \text { 000: } 41 \% \\
\text { Above EUR } 75 \text { 000: } 43 \%\end{array}$ & $\begin{array}{l}\text { Below EUR } 80 \text { 000: } 15 \% \\
\text { Above EUR } 80 \text { 000: } 20 \%\end{array}$ \\
\hline $\begin{array}{l}\text { Subnational } \\
\text { income } \\
\text { taxes: }\end{array}$ & $\begin{array}{l}\text { Regional taxes: Income below EUR } 15000: 1.73 \% \\
\text { Income EUR } 15000 \text { or higher: } 3.33 \% \text {. } \\
\text { Local taxes: standard rate of } 0.2 \% \text {, ranging up to } 0.9 \% \text {. }\end{array}$ & Maintain existing rates \\
\hline $\begin{array}{l}\text { Social } \\
\text { security } \\
\text { contributions: }\end{array}$ & $\begin{array}{l}\text { Income up to EUR } 46 \text { 630: } 9.49 \% \\
\text { Income EUR } 46630 \text { to EUR } 101427: 10.49 \% \\
\text { Income above EUR } 101 \text { 427: Fixed at EUR } 10173.39\end{array}$ & Maintain existing rates \\
\hline $\begin{array}{l}\text { Family tax } \\
\text { credits and } \\
\text { allowances: }\end{array}$ & $\begin{array}{l}\text { Family tax credits are granted to taxpayers living with a } \\
\text { dependant spouse, children, and other relatives, } \\
\text { provided the dependent's annual income does not } \\
\text { exceed EUR } 2840.51 \\
\text { Spouse/other dependent relatives: EUR 800/EUR } 750 \\
\text { decreasing to EUR } 0 \text { for net income over EUR } 80000 \text {. } \\
\text { Children under 3/over } 3 \text { : EUR } 1220 \text { / EUR } 950 \\
\text { decreasing to } 0 \text { for net income over EUR } 95000 \text {. Higher } \\
\text { for families with disabled children or 4+ children }\end{array}$ & $\begin{array}{l}\text { Replace existing tax credits with a tax allowance which } \\
\text { is deducted from family taxable income. } \\
\text { For family taxable income: } \\
\text { Below EUR } 35000 \text { : EUR } 3000 \text { x number of family } \\
\text { members; } \\
\text { EUR } 35000 \text {-EUR } 50000 \text { : EUR } 3000 \text { x number of } \\
\text { dependents; } \\
\text { Above EUR } 50000 \text { : zero. }\end{array}$ \\
\hline $\begin{array}{l}\text { Other tax } \\
\text { credits: }\end{array}$ & $\begin{array}{l}\text { Tax credits generally at } 19 \% \text { of an expense: interest, } \\
\text { medical, education, rent, childcare, life and accident } \\
\text { insurance expenses. }\end{array}$ & Maintain existing tax credits \\
\hline Other: & & Tax liability is the least of Scenario A and B. \\
\hline
\end{tabular}

Source: OECD Tax and benefit database and authors' simulations.

41. Compared with 2018 policies, lowering and flattening statutory tax rates would raise disposable incomes across household types but high income households would benefit more (Figure 11-Panel B). This would lead disposable income inequality to rise by $4.4 \%$ when measured by the quintile ratio (ratio of incomes of the households at the $20^{\text {th }}$ and $80^{\text {th }}$ percentile), even after accounting for the support to low income households from the Citizen's Income. 
Figure 11. Guaranteed minimum incomes boost very low income households while flattened personal income tax rates would largely benefit higher income households

Percentage change in net equivalised disposable income by income decile

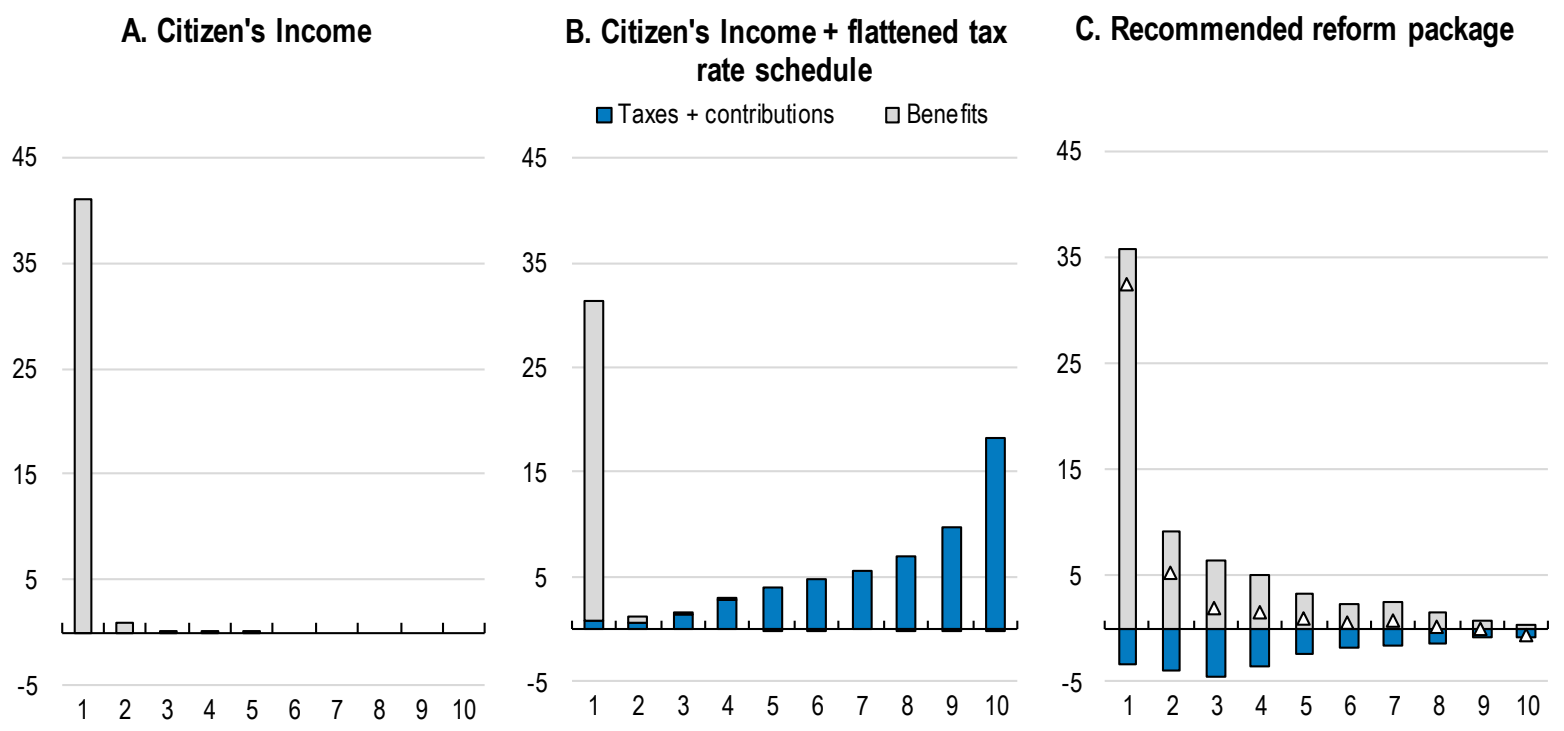

Source: OECD calculations using EUROMOD. See source notes to Figure 8.

42. Flattening the personal income tax rates risks entrenching social and regional disparities. For low income households eligible for the CI, the reform would not improve work incentives. For high income households, which are not eligible for the CI, reducing marginal tax rates would further encourage households to increase their already relatively high work hours, such as by second earners entering the workforce. But employment rates are already relatively high in richer regions and where a larger share of workers would benefit from lower income tax rates.

43. Moreover, flattening personal income tax rates would substantially lower fiscal revenues and generate large fiscal costs. Simulations suggest the tax rate reforms described in Table 9 would have an immediate direct cost of EUR 61 billion annually (Table 6 and Table 7).

\subsection{Reforming the guaranteed minimum income and introducing in-work benefits would raise poor households' incomes}

44. This sub-section proposes and analyses a reform package, which includes reforming the $\mathrm{CI}$ and introducing in-work benefits. More specifically, the proposed reforms combine the following elements: 1) a guaranteed minimum income, which recalibrates the current CI income by lowering transfers and gradually withdrawing them as beneficiaries start working; 2) in-work benefits for low-income earners; 3) a progressive income tax system that is simplified by consolidating tax credits, and 4) a simplified family benefit. Table 10 summarises the package. 
Table 10. A proposed tax and benefit reform package introducing low-wage in-work benefits, a refined guaranteed minimum income scheme and simpler personal income tax system

\begin{tabular}{|c|c|}
\hline \multicolumn{2}{|c|}{ Low-income in-work benefits: } \\
\hline & $\begin{array}{l}\text { Provide an in-work benefit based on the individual's gross earnings less social security contributions. Amounts } \\
\text { and earnings thresholds depend on the number of dependent children. Benefit amounts increase linearly with } \\
\text { earnings up to a given threshold, then they remain constant and finally decrease linearly for higher earnings } \\
\text { levels. }\end{array}$ \\
\hline \multicolumn{2}{|c|}{ Guaranteed minimum income: } \\
\hline Transfer, for a single adult: & Income transfer of up to EUR 3600 / year. \\
\hline $\begin{array}{l}\text { Equivalence scale } \\
\text { adjustment for household } \\
\text { size: }\end{array}$ & OECD equivalence scale of square root of number of household members, regardless of their age. \\
\hline Duration: & Indefinite subject to meeting requirements of participating in active labour market or social support programmes. \\
\hline Other benefits: & Unemployment benefit recipients eligible if meet eligibility criteria. \\
\hline Interaction with wages: & Earnings disregard of $25 \%$ - i.e., earnings are discounted by $25 \%$ when assessing eligibility and transfer. \\
\hline Income eligibility: & $\begin{array}{l}\text { Household reference income based on the ISEE Income Situation Index before deductions included in the ISEE } \\
\text { calculation. Abolish the ISEE income eligibility threshold of EUR } 3000 \text {. }\end{array}$ \\
\hline Asset eligibility: & $\begin{array}{l}\text { Same asset eligibility conditions as the Citizen's Income: value of real estate assets (excluding the main } \\
\text { residence) below EUR } 30000 \text {. Does not own a vehicle. Moveable property assets below EUR } 6000 \text { for single } \\
\text { persons, raised by EUR } 2000 \text { for each additional family member up to EUR } 10000 \text { (increased by EUR } 1000 \text { for } \\
\text { each child after the second) and by EUR } 5000 \text { more for a disabled household member. }\end{array}$ \\
\hline Residency: & Non-EU Citizens must have been resident for at least 5 years. \\
\hline \multicolumn{2}{|l|}{ Personal income taxes: } \\
\hline $\begin{array}{l}\text { Simplify the income tax } \\
\text { system and make it more } \\
\text { progressive: }\end{array}$ & $\begin{array}{l}\text { Abolish family-related tax credits (for dependent spouse, for dependent children, for dependent relatives, for large } \\
\text { families and for childcare expenses), and replace them with a new family benefit (see below). } \\
\text { Abolish the fiscal bonus and replace it with a new in-work benefit (see above). } \\
\text { Increase the two highest marginal tax rates (from } 41 \text { to } 43 \% \text { and from } 43 \% \text { to } 45 \% \text { ). }\end{array}$ \\
\hline \multicolumn{2}{|l|}{ Family benefits: } \\
\hline & $\begin{array}{l}\text { Abolish the family allowance for employees ("assegni al nucleo familiare"), the allowance for large families } \\
\text { ("assegno alle famiglie numerose"), the 'infant/bebé bonus' and the 'new mothers bonus'. } \\
\text { Replace them with a new family allowance, with the allowance amount depending on the household's ISEE value. }\end{array}$ \\
\hline \multicolumn{2}{|l|}{ Housing benefits: } \\
\hline & $\begin{array}{l}\text { Providing a housing cost supplement to the guaranteed minimum income benefit of up to EUR } 2400 \text { / year, } \\
\text { scaled by household size using the equivalence scale described above. }\end{array}$ \\
\hline
\end{tabular}

Note: Detailed schedules of the proposed family benefits and in-work benefits are provided in Table 3 Source: OECD.

\subsubsection{In-work benefits would support low-wage earners and improve employment incentives}

45. A growing number of OECD countries have introduced in-work benefits, and found that they can raise employment rates and incomes of poor households at lower cost than direct transfers to households. Also known as make-work-pay policies, in-work benefits provide a net income transfer to individuals or to households working a minimum number of hours and with employment incomes below specified thresholds. They can also be more effective at raising employment income for poorer households than increasing the minimum wage, which may the amount of low-wage work available. However in-work benefits may be ineffective if recipients would have started to work or sought more hours even without the benefit. They may also depress wage growth if employers discriminate among workers by cutting the wage of those claiming in-work benefits (Azmat, 2006[29]).

46. Whether in-work benefits are assessed against household or individual income influences how the benefit impacts on employment and income. Assessing eligibility against household income improves the targeting of the benefit towards poorer households. 
Analysis of similar schemes in several countries finds that it can increase the employment levels of primary earners. But assessing benefits against overall household income can lead to high effective tax rates when entering employment for the second earner. If the second earner starts earning employment income and the total household income rises above certain thresholds, all earners in the household may become ineligible for the benefit. This leads to lower work effort and employment rates among second earners (Brender and Strawczynski, 2018 [30]; Eissa and Hoynes, 2004[31]; Luca, Rossetti and Vuri, 2014 $\left.{ }_{[32]}\right)$.

47. In Italy, an in-work benefit programme should assess eligibility against the individual earner's rather than the household's income. Low labour force participation rates among second earners and the importance that these have in explaining persistent regional disparities in living standards (OECD, 2019 $\left.{ }_{[1]}\right)$ make improving work incentives among second earners the priority of tax and benefit reforms. In contrast, if the benefit is assessed against individual income, then one earner in a household may retain the benefit even as another household member enters or increases work.

48. The proposed in-work benefits would top-up low-wage earners' incomes and ensure that beneficiaries' net income rises as they earn higher wage income (Table 2 and Figure 1 show the in-work benefit at selected gross wage rates). This goes further than the existing system of tax credits. Among other benefits and credits, this would replace the existing low income tax credit and the EUR 80 per month fiscal bonus for lower-middle income earners. This is visible in Figure 6, Panel D, where the in-work benefits (light blue area) raise net income (solid back line) as gross earnings rise from zero to $50 \%$ of the average wage. This results in a low effective tax rate when entering employment at low wages (Figure 5). This is in contrast with the Citizen's Income (Figure 6, Panel B) where the net income rises little as gross employment earnings increase from zero to $50 \%$, resulting in a high effective tax rate when entering employment (Figure 5).

49. The proposed reform package simplifies the tax system by consolidating the currently fragmented employment-related family support into a single family allowance, including the EUR 80 per month fiscal bonus, the working family allowance and the family tax credits. This consolidated in work benefit includes a 'phase-in' region for low-wage earners who do not benefit from the current fiscal bonus, and a larger phase-out region, reducing the high marginal effective tax rate of the current rapid phase out. The amounts and thresholds of the proposed allowance depend on the number of dependent children, so as to unify the current family tax credit, employee family allowances and fiscal bonus into a single streamlined programme. Combined with the in-work benefit, this family allowance reduces the effective tax rates on entering employment at low wages faced by second earners (Figure 5). Table 3 and Figure 2 present the proposed consolidated family allowance values.

\subsubsection{Guaranteed minimum income benefits that taper off with rising incomes would provide a safety net against poverty and avoid poverty traps}

50. Modest benefits that gradually decline as gross earnings rise would better address the trade-off between reducing poverty and encouraging work than the Citizen's Income. The proposed reform package would include a guaranteed minimum income that provides a safety net for households with no or very low income (Table A.1 reports the transfers of the proposed reform package's guaranteed minimum income scheme for selected household types). Transfer amounts would be greater than the REI but lower than the CI (Figure 3; Figure 6 comparing panels B and D; Table 10). These larger transfers would reduce poverty and inequality compared with the 2018 policies with the REI and the CI (Table 6). 
51. For a single person, the guaranteed minimum income transfers would start at EUR 6000 (EUR 500 per month) when the beneficiary is not earning any employment income and has a regular rental contract. This is made up of a benefit of EUR 3600 per year plus a 'rent' component of EUR 2400 per year for tenants. The rent component is adjusted for the household size. While this is not part of the proposed reform package, the rent component could also be adjusted for the differences in the cost of living between different areas of Italy. This could draw upon ISTAT's methodology for calculating Italy's absolute poverty lines, which are functions of the geographic area (North, Centre and South of Italy) and size of the municipality of residence $(250000,250$ 000-50 000, less than 50000 inhabitants). Adjusting the rental component in this way would improve the proposed guaranteed minimum income's targeting and equity between regions, and is likely to reduce its total cost.

52. The transfer amounts would decrease gradually as a beneficiary starts earning income. The transfer value declines progressively as the beneficiary earns higher income. For example, if the beneficiary earns gross employment income of EUR 5700 (net of employee social security contributions), they would still receive around EUR 1000 through the guaranteed minimum income. Once the beneficiary's gross earnings reach EUR 7200 (EUR 600 per month) they become ineligible for guaranteed minimum income transfers. While guaranteed minimum income transfers decline with higher gross earnings, the beneficiary also becomes eligible for the in-work benefit. Its maximum value is EUR 1000 per year at gross earnings of EUR 7200 . The tapering of the guaranteed minimum income benefit, combined with in-work benefits, ensures that net income rises faster as gross earnings increase. This lowers the high effective tax rate (ETRs) observed with the current design (Figure 5 and Figure 7 respectively).

53. All members of a household receiving the guaranteed minimum income would be obliged to participate in a programme tailored to the recipients' needs. For most beneficiaries this programme would focus on job search and training, and can also include other social support programmes for households with multidimensional needs. These would mirror the requirements of the REI. Like the REI and CI programmes, this requirement will need to be matched by efforts to strengthen the capacity of public employment and other social services across all regions.

\subsubsection{The proposed reform package would lift employment and activity, and generate additional revenues}

54. The recommend reform package maintains and strengthens the progressivity of the current personal income tax system. The highest marginal statutory tax rates would rise from $41 \%$ to $43 \%$ and from $43 \%$ to $45 \%$ (Table 10 ). The proposed reform package would reduce income inequality and poverty by $10.5 \%$ and $8.6 \%$ respectively compared with 2018 policies (Table 6). In the longer-term, the reform package is likely to boost employment, supporting incomes and activity. Macroeconomic simulations, based on Guillemette and Turner $\left(2018_{[15]}\right)$, suggest that the employment rate would rise by $2.4 \%$ in 2030 relative to the baseline of 2018 policies (Table 8), largely through the reform package's reduced labour income tax wedge for lower and middle income workers. This effect may be greater in lagging regions where employment rates are lower, and so this reform package may reduce regional disparities over the longer term.

55. Overall, in the short term, the proposed reform package would raise additional tax revenues of EUR 11 million compared with 2018 policies. Because of higher social transfers, due mainly to the introduction of in-work benefits, the proposed reform package's net fiscal cost would be around EUR 8 billion (Table 7), which is slightly higher than the CI's expected cost when it is fully implemented. Over the medium long term, the proposed 
reform package would lift overall employment and activity, generating additional public revenues equivalent to $0.4 \%$ of GDP by 2025 rising to $1.4 \%$ by 2040 , compared with 2018 policies (Table 8). This would exceed the reform package's simulated cost.

\section{Summary and conclusion}

56. In recent years Italy has made progress in reforming its benefit system to better support poor households. Recent reforms have introduced a national social safety net through a guaranteed minimum income for very low income households, who have previously benefited little from Italy's social transfers.

57. However, these policies combined with the high tax and contributions wedge on income discourage work at low incomes and among second earners, through further raising the effective tax rate on entering employment and marginal tax rates when working hours or pay rates increase. These long-standing disincentives to enter the formal labour market contribute to Italy's wide social and regional disparities, discussed in OECD (2019 $\left.{ }_{[1]}\right)$. Requirements that beneficiaries seek and accept work will only be effective if the administrative capacity of the public employment services markedly improves.

58. This study proposes a reform package can build on recent improvements in Italy's social protection system by recalibrating the Citizen's Income and complementing it with in-work benefits for low-wage workers. Combined with a simplified but still progressive personal income tax system, this reform package can reduce poverty and inequality while encouraging employment and activity. By maintaining progressive income tax rates, the initial net fiscal cost of this reform package would be modest. In the longer-term, by encouraging employment, particularly in lagging regions where employment rates are low, this package would raise employment and activity and generate additional public revenues that more than offset its cost. 


\section{Annex. Proposed reform package of guaranteed minimum income, in-work benefits and family allowances}

\section{Proposed guaranteed minimum income}

Eligibility requirements:

- Claimants must reside in Italy for at least 5 years.

- Value of real estate property, with the exclusion of the main residence must be below EUR 30 000. This value is the same as the 'asset component' of the ISEE indicator.

- Value of movable assets must be below EUR 6000 . This is the same value as the second part of the asset component of the ISEE indicator. This value is increased by EUR 2000 for each household member after the first member, up to a maximum of EUR 10 000. The EUR 10000 threshold is increased by EUR 1000 for each child after the second child. The EUR 6000 and EUR 10000 thresholds are increased by EUR 5000 if there is a household member with a disability.

- Unlike the Citizen's Income policy, there are no ISEE or income-related eligibility thresholds.

Calculation of benefit amounts:

- Equivalence scale: square root of the household size. The household size is defined as in the ISEE declaration.

- Definition of household income: income component of the ISEE indicator before any ISEE deductions (e.g. the deduction of $20 \%$ of earnings up to EUR 3000 ). The income base does not include the disability allowance for those with maximum disability ("assegno di accompagnamento") as well as any social assistance benefits received while claiming the new GMI.

- Benefit amount for a single person: EUR 300 per month (EUR 3600 / year) plus a 'rent' component of EUR 200 per month for tenants (EUR 2400 / year). Unlike the CI, the rent component is adjusted for the household size.

- The programme disregards $25 \%$ of in-work earnings when assessing eligibility and transfer.

As an additional feature that is not included in the proposed reform package simulated in this paper, the rent component could be adjusted for the differences in the cost of living between different part of the country. The adjustment could draw upon ISTAT's calculation of absolute poverty lines, which are functions of the geographic area (North, Centre and South of Italy) and size of the municipality of residence (250 000, $250000-50000$, less than 50000 inhabitants). 
Table 1. Schedule of proposed guaranteed minimum income transfer values

Maximum benefit amounts (EUR per year), by household size and benefit component

\begin{tabular}{c|c|c|c}
\hline $\begin{array}{c}\text { Number of } \\
\text { household members }\end{array}$ & $\begin{array}{c}\text { Maximum basic } \\
\text { benefit amount }\end{array}$ & $\begin{array}{c}\text { Maximum housing } \\
\text { cost supplement }\end{array}$ & $\begin{array}{c}\text { Maximum total } \\
\text { benefit amount }\end{array}$ \\
\cline { 1 - 4 } & 3600 & 2400 & 6000 \\
\hline 2 & 5091 & 3394 & 8485 \\
\hline 3 & 6235 & 4157 & 10392 \\
\hline 4 & 7200 & 4800 & 12000 \\
\hline 5 & 8050 & 5367 & 13416 \\
\hline 6 & 8818 & 5879 & 14697 \\
\hline
\end{tabular}

Note: For households containing more than six family members the benefit increases according to the OECD equivalence scale which is the square root of the household size.

Source: OECD

\section{Proposed in-work benefit}

\section{Figure 1. Proposed in-work benefit}

By gross earnings, EUR per year

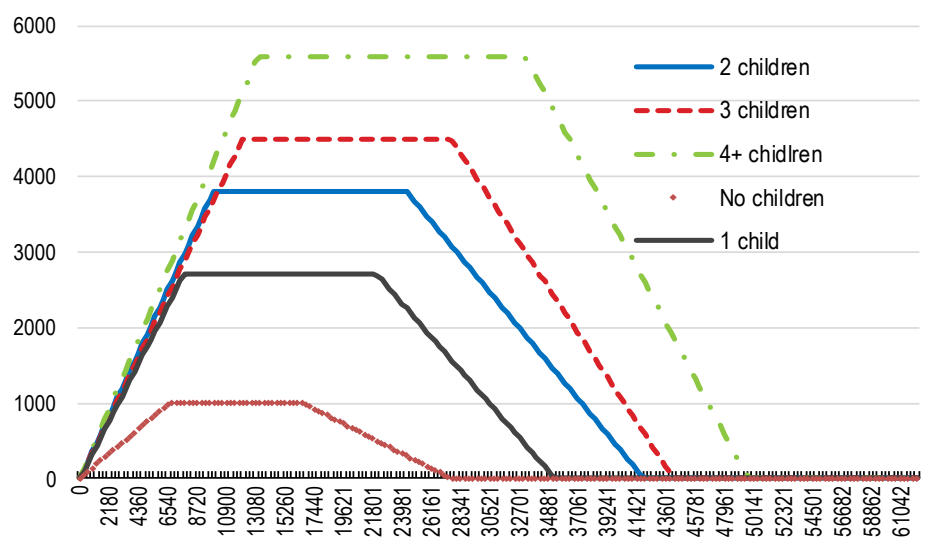

Note: The horizontal axis shows gross individual in-work earnings after social security contribution payments.

Source: OECD

Table 2. Schedule of proposed in-work benefits

In-work benefit design, EUR per year

\begin{tabular}{lcccc}
\hline \multicolumn{1}{c}{ Family type } & $\begin{array}{c}\text { Phase-in income } \\
\text { range }\end{array}$ & $\begin{array}{c}\text { Plateau income } \\
\text { range }\end{array}$ & $\begin{array}{c}\text { Phase-out income } \\
\text { range }\end{array}$ & $\begin{array}{c}\text { Maximum amount per } \\
\text { adult }\end{array}$ \\
\hline Family with no children & $0-6000$ & $6001-15000$ & $15001-25000$ & 1000 \\
Family with one child & $0-7000$ & $7001-20000$ & $7001-32000$ & 2700 \\
Family with two children & $0-9000$ & $9001-22000$ & $9001-38000$ & 3800 \\
Family with three children & $0-11000$ & $11001-25000$ & $11001-40000$ & 4500 \\
$\begin{array}{l}\text { Family with four or more } \\
\text { children }\end{array}$ & $0-13000$ & $13001-30000$ & $13001-45000$ & 5600 \\
\hline
\end{tabular}

Note: Only children up to 18 years old are considered. The phase-in, plateau and phase-out income ranges refers to the gross individual in-work earnings after social security contribution payments. The in-work benefit enters the means tests of both the GMI benefit and the family allowance. 
Source: OECD.

\section{Proposed family allowance}

Table 3. Schedule of proposed family allowance

\begin{tabular}{|c|c|c|c|c|}
\hline Family type & $\begin{array}{c}\text { Amount for lone } \\
\text { parents (EUR / year) }\end{array}$ & $\begin{array}{c}\text { Amount for couples } \\
\text { (EUR / year) }\end{array}$ & $\begin{array}{l}\text { Maximum benefit } \\
\text { income range }\end{array}$ & $\begin{array}{c}\text { Phase-out income } \\
\text { range }\end{array}$ \\
\hline $\begin{array}{l}\text { Family with one } \\
\text { child }\end{array}$ & 2500 & 2000 & \multirow{4}{*}{$0-7000$} & \multirow{4}{*}{$7001-25000$} \\
\hline $\begin{array}{l}\text { Family with two } \\
\text { children }\end{array}$ & 4500 & 3700 & & \\
\hline $\begin{array}{l}\text { Family with three } \\
\text { children }\end{array}$ & 6500 & 6000 & & \\
\hline $\begin{array}{l}\text { Family with four or } \\
\text { more children }\end{array}$ & 8500 & 7500 & & \\
\hline
\end{tabular}

Note: The maximum and phase-out income ranges refer to the household's ISEE indicator. The new family allowance would enter the means test of the new GMI benefit.

Source: OECD.

Figure 2. Proposed family allowance

By gross earnings, percent of average wage

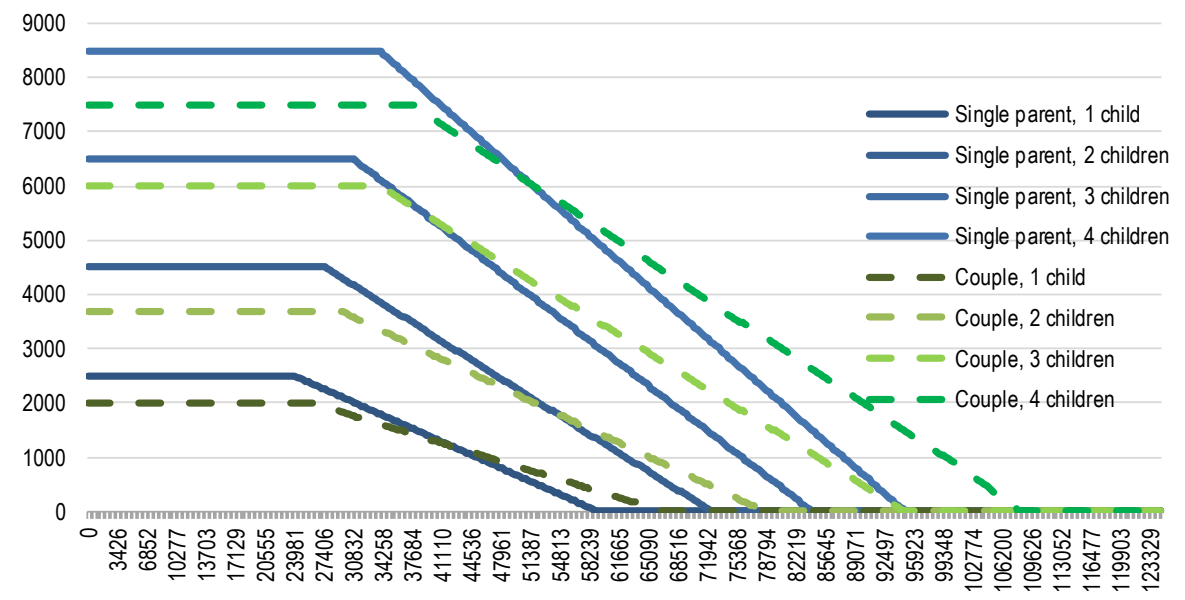

Note: The horizontal axis shows gross individual in-work earnings after social security contribution payments. Source: OECD. 


\section{References}

Alm, J. (2005), "Taxing the "Family" in the Individual Income Tax", Public Finance and Management, Vol. 5/1, pp. 67-109, https://www.researchgate.net/publication/241558261 (accessed on 9 January 2019).

Azmat, G. (2006), “The Incidence of an Earned Income Tax Credit: Evaluating the Impact on Wages in the UK", CEP Discussion Papers.

Bachelet, M. et al. (2018), Assessing Policy Reforms Using Output from the OECD Tax-benefit Model: Description of the policy evaluation scoreboard, OECD, Paris, http://www.oecd.org/els/soc/policyevaluation-scoreboard-overview.pdf (accessed on 23 January 2019).

Baldini, M. et al. (2018), “The Impact of REI on Italian Households' Income: A Micro and Macro Evaluation”, SSRN, http://dx.doi.org/10.2139/ssrn.3167745.

Bargain, O., K. Orsini and A. Peichl (2013), "Comparing Labor Supply Elasticities in Europe and the US: New Results”, SSRN, http://dx.doi.org/10.2139/ssrn.2197817.

Bargain, O. and A. Peichl (2013), Steady-State Labor Supply Elasticities: An International Comparison, https://halshs.archives-ouvertes.fr/halshs-00805744.

Batty, E. et al. (2015), Homeless people's experiences of welfare conditionality and benefit sanctions, Crisis, London, http://www.crisis.org.uk.

Bodewig, C. et al. (2016), "Greece Social Weflare Review: Weathering the Crisis: Reducing the Gaps in Social Protection in Greece”.

Boeri, T. (2019), Audizione Presidenza Senato Roma, INPS, 4 febbraio 2019 Tito Boeri, https://www.inps.it/docallegatiNP/Mig/Allegati/Audizione_Presidente Boeri 3.1.pdf.

Brender, A. and M. Strawczynski (2018), "The Employment Effects of the EITC Program in Israel: Evidence on the Differential Effect of Family vs. Individual-Income Based Designs", https://portal.oecd.org/eshare/eco/pc/Deliverables/BBS/Background\%20material/14\%20Dec\%20\%20M.\%20Strawczynski.pdf.

Browne, J. and H. Immervoll (2017), "Mechanics of replacing benefit systems with a basic income: comparative results from a microsimulation approach", The Journal of Economic Inequality, Vol. 15/4, pp. 325-344, http://dx.doi.org/10.1007/s10888-017-9366-6.

Causa, O., M. Hermansen and N. Ruiz (2016), "The Distributional Impact of Structural Reforms”, OECD Economics Department Working Papers, No. 1342, OECD Publishing, Paris, https://dx.doi.org/10.1787/5jln041nkpwc-en.

Colonna, F. and S. Marcassa (2015), “Taxation and female labor supply in Italy”, IZA Journal of Labor Policy, http://dx.doi.org/10.1186/s40173-015-0030-0. 
Commissione 11a del Senato della Repubblica (2019), Audizione del Presidente dell'Ufficio parlamentare di bilancio DDL n. 1018 - Conversione in legge del DL 28 gennaio 2019, n. 4 recante disposizioni urgenti in materia di reddito di cittadinanza e di pensioni, Italian Senate, Rome, http://www.upbilancio.it/wp-content/uploads/2019/02/Audizione_5_2_2019_Pisauro.pdf.

Crepaldi, C. et al. (2017), Minimum Income Policies in EU Member States, European Parliament, [26] http://www.europarl.europa.eu/RegData/etudes/STUD/2017/595365/IPOL_STU\%282017\%29595365 EN.pdf.

De Mooij, R. and M. Keen (2012), “Fiscal Devaluation” and Fiscal Consolidation: The VAT in Troubled Times.

Dwyer, P. and S. Wright (2014), "Universal Credit, ubiquitous conditionality and its implications for social citizenship", Journal of Poverty and Social Justice, Vol. 22/1, pp. 27-35, http://dx.doi.org/10.1332/175982714x13875305151043.

Eissa, N. and H. Hoynes (2004), "Taxes and the labor market participation of married couples: the earned income tax credit", Journal of Public Economics, Vol. 88/9-10, pp. 1931-1958, http://dx.doi.org/10.1016/j.jpubeco.2003.09.005.

European Commission (2018), 2018 European Semester: Assessment of progress on structural reforms, prevention and correction of macroeconomic imbalances, and results of in-depth reviews under Regulation (EU) No 1176/2011, European Commission, Brussels, https://ec.europa.eu/info/sites/info/files/2018-european-semester-country-reportcommunication_en.pdf.

European Commission (2018), Compliance Report, ESM Stability Support Programme for Greece, Third Review, European Commission, https://ec.europa.eu/info/sites/info/files/economyfinance/compliance report_3r to ewg_2018 03 02_1.pdf.

European Commission (2018), The 2018 Ageing Report: Economic and budgetary projections for the 28 EU Member States (2016-2070), European Commission, http://dx.doi.org/10.2765/615631 (accessed on 6 January 2019).

Frazer, H. and E. Marlier (2009), Minimum Income Schemes Across EU Member States - Synthesis report, European Commission.

Ghetti, V. (2012), Il Fattore Famiglia Lombardo: una sperimentazione opportuna?, http://www.lombardiasociale.it/2012/09/19/il-fattore-famiglia-lombardo-una-sperimentazioneopportuna/ (accessed on 28 September 2018).

Guillemette, Y. and D. Turner (2018), “The Long View: Scenarios for the World Economy to 2060", OECD Economic Policy Papers, No. 22, OECD Publishing, Paris, https://dx.doi.org/10.1787/b4f4e03e-en.

Immervoll, H. et al. (2011), “Optimal tax and transfer programs for couples with extensive labor supply responses", Journal of Public Economics, Vol. 95/11-12, pp. 1485-1500, http://dx.doi.org/10.1016/j.jpubeco.2011.06.005.

Iudicone, F. (2017), Italy: Latest working life developments-Q4 2016, Eurofoound, https://www.eurofound.europa.eu/publications/article/2017/italy-latest-working-lifedevelopments- q42016. 
Johansson, Å. (2016), "Public Finance, Economic Growth and Inequality: A Survey of the Evidence", OECD Economics Department Working Papers, No. 1346, OECD Publishing, Paris, http://dx.doi.org/10.1787/094bdaa5-en.

Luca, G., C. Rossetti and D. Vuri (2014), "In-work benefits for married couples: an ex-ante evaluation of EITC and WTC policies in Italy”, IZA Journal of Labor Policy, http://dx.doi.org/10.1186/2193-9004$\underline{3-23}$.

Marini, A. et al. (2019), A Quantitative Evaluation of the Greek Social Solidarity Income, World Bank, http://documents.worldbank.org/curated/en/882751548273358885/pdf/133962-WP-P160622Evaluation-of-the-SSI-Program-Jan-2019.pdf (accessed on 11 February 2019).

Ministry of Economy and Finance (2017), 2018 Round of EPC-WGA Projections - Italy's Fiche on Pensions, https://ec.europa.eu/info/sites/info/files/economy-finance/final country fiche it.pdf.

Motta, M. (2011), "Le criticità dell'Isee”, Prospettive Socili e Sanitarie, Vol. 2011/16-18, pp. 9-12, https://prospettivesocialiesanitarie.it/irpet/appendice-irpet_PSS1116-18.pdf (accessed on 28 September 2018).

Nichols, A. and J. Rothstein (2015), The Earned Income Tax Credit (EITC), National Bureau of Economic Research, Cambridge, MA, http://dx.doi.org/10.3386/w21211.

OECD (2019), OECD Economic Surveys: Italy 2019, OECD Publishing, Paris.

OECD (2019), Taxing Wages 2019, OECD Publishing, Paris, https://dx.doi.org/10.1787/tax_wages-2019en.

OECD (2018), Good Jobs for All in a Changing World of Work: The OECD Jobs Strategy, OECD Publishing, Paris, https://dx.doi.org/10.1787/9789264308817-en.

OECD (2018), OECD Economic Surveys: Greece 2018, OECD Publishing, Paris, http://dx.doi.org/10.1787/eco surveys-grc-2018-en.

OECD (2017), OECD Economic Surveys: Italy 2017, OECD Publishing, Paris, http://dx.doi.org/10.1787/eco surveys-ita-2017-en.

OECD (2015), OECD Economic Surveys: Italy 2015, OECD Publishing, Paris, http://dx.doi.org/10.1787/eco_surveys-ita-2015-en.

OECD (2013), OECD Economic Surveys: Italy 2013, OECD Publishing, Paris, http://dx.doi.org/10.1787/eco surveys-ita-2013-en.

OECD (2011), Taxation and Employment, OECD Tax Policy Studies, No. 21, OECD Publishing, Paris, http://dx.doi.org/10.1787/9789264120808-en.

OECD (2003), OECD Economic Survey of Italy, OECD, Paris, http://www.oecd.org.

OECD (2019, forthcoming), TaxBEN: The OECD tax-benefit model, OECD.

Pacifico, D. et al. (2018), "Faces of Joblessness in Italy: A People-centred perspective on employment barriers and policies", OECD Social, Employment and Migration Working Papers, No. 208, OECD Publishing, Paris, http://dx.doi.org/10.1787/e5d510c2-en. 
Pareliussen, J., H. Hwang and H. Viitamäki (2018), "Basic income or a single tapering rule? Incentives, inclusiveness and affordability compared for the case of Finland", OECD Economics Department Working Papers, No. 1464, OECD Publishing, Paris, https://dx.doi.org/10.1787/d8c0fbc4-en.

Sacchi, S. (2018), “The Italian Welfare State in the Crisis: Learning to Adjust?”, South European Society and Politics, http://dx.doi.org/10.1080/13608746.2018.1433478.

Strati, F. (2009), Italy Minimum Income Schemes A Study of National Policies, European Commission, Brussels, http://www.peer-review-social-inclusion.eu.

Sutherland, H. and F. Figari (2013), EUROMOD: the European Union tax-benefit microsimulation model, http://www.flemosi.be.

Thomas, A. and P. O'Reilly (2016), “The Impact of Tax and Benefit Systems on the Workforce Participation Incentives of Women”, OECD Taxation Working Papers, No. 29, OECD Publishing, Paris, http://dx.doi.org/10.1787/d950acfc-en.

Work and Pensions Committee (2018), Benefit Sanctions, House of Commons, London, https://publications.parliament.uk/pa/cm201719/cmselect/cmworpen/955/955.pdf (accessed on 22 January 2019).

Wright, S. et al. (2016), First Wave Findings: Universal Credit, Economic and Social Research Council, York, http://www.welfareconditionality.ac.uk (accessed on 22 January 2019). 